УДК 351.852.15:355.1(477)

DOI: $10.33099 / 2707-1383-2020-38-4-100-128$

Міненко Л.М., аспірантка,

Наиіональна академія керівних кадрів

культури і мистецтв

(м. Київ, Україна)

ORCID: https://orcid.org/0000-0003-0249-9856

\title{
ФОРМУВАННЯ МЕРЕЖІ ВІЙСЬКОВИХ МУЗЕЇВ У ЗБРОЙНИХ СИЛАХ УКРАЇНИ (1995-2013 рр.)
}

\begin{abstract}
Анотація. У статті викладено передумови становлення і розвитку мережі військових музеїв (музейних утворень) Збройних Сил України (ЗС Украӥни) як основи для побудови системи виховної і соціально-психологічної роботи у період з 1995 по 2013 роки. Конкретизовано місие й роль Наиіонального військово-історичного музею України (НВІМУ) і його філій як головних дієвих учасників иієї системи. Проаналізовано діяльність музейних установ ЗС Украӥни згідно показників, що відображають структуру фондів і культурно-освітню роботу. Візуалізовано підсумки роботи військових музеїв, що входять у структуру Міністерства оборони України, Генерального штабу та Управління розвідки ЗС України.

Ключові слова: Національний військово-історичний музей Украӥни; філія НВIМУ; мережа військових музеїв Збройних Сил Украйни; система виховної і соиіально-психологічної роботи у Збройних Силах Украӥни; інформащійно-музейна діяльність; фонди музейних утворень.
\end{abstract}

Постановка проблеми. Питання системного вдосконалення діяльності військової музейної мережі виникли і стали гостро актуальними у період, коли Україна здобула незалежність. 3'явилася беззаперечна необхідність формування у громадян, у першу чергу - серед військовослужбовців,відповідних аксіологічно-патріотичних рис, які б зміцнювали національну безпеку. Фактично, 3 цього моменту розпочалася кропітка робота по організації належного, якісно-нового рівня виховання громадян та, особливо, військовослужбовців, які приймали присягу на вірність народу України. Мусимо визнати, що факт прийняття присяги не був гарантією адекватних патріотичних почуттів. Часто це було проявом звичайного пристосування для подальшого кар'єрного росту і до всіх видів соціального забезпечення, що військовослужбовець мав отримати у 1991 році, під час виходу України зі складу СРСР. За таких обставин виникла необхідність нових підходів до формування національної системи виховної і соціально-психологічної роботи у Збройних Силах України (ЗС України). Застосування сучасних форм аксіологічно-патріотичного виховання мало сприяти пробудженню української свідомості, як головної умови національної безпеки та оборони молодої держави.

Основою для побудови дієвої системи виховної і соціально-психологічної роботи у ЗС України стала мережа військових музеїв. Аналіз джерел дозволяє оцінити 
етапи становлення і функціонування такої мережі, а також дослідити та визначити місце і роль Національного військово-історичного музею України (НВIMУ), його філій, як головних учасників вказаної системи,у період з 1995 по 2013 роки. Нижня хронологічна межа дослідження визначає рік створення (1995 рік) Музею Збройних Сил України (МЗСУ). Верхня хронологічна межа (2013 рік) - фіксує історичну віху музею і шести його філій у статусі Національного. Це був період сталого розвитку головної військової музейної установи, що на наше переконання дає можливість об'єктивно оцінити отримані здобутки, проаналізувати умови досягнення позитивних результатів. Крім того, верхня хронологічна межа взята до уваги через трансгресивні події в Україні у 2013-2014 роках, коли відбулася Революція Гідності, розпочалася російська збройна агресія, територія Автономної Республіки Крим, де функціонували дві філії НВІМУ у м. Севастополі, була анексована Російською Федерацією.

Аналіз досліджень і публікацій. Публікації, що розміщені у друкованих виданнях, характеризують етапи становлення й розвитку Національного військово-історичного музею України (НВIМУ з 2010 року; до 1997 року - Музей Збройних Сил України (МЗСУ); до 2010 року — Центральний музей Збройних Сил України (ЦМЗСУ)) і його філій та окремих військових музеїв нашої держави (додаток 1). Серед наукових праць $\epsilon$ такі, що за своїм змістом розкривають організацію діяльності військових музейних установі містять ряд оригінальних, на нашу думку, прикладів, які можна віднести до позитивних управлінських практик. Зокрема, у 2000 році, на публічний огляд було представлено Положення про музеї та музейну справу у Збройних Си- лах України (ЗС України), Положення про Центральний музей ЗС України (ЦМЗСУ) i Положення про фондово-закупівельну комісію ЦМЗСУ [3]. У 2006 році, у «Концепції Національного військово-історичного музею України» (Концепція)- обгрунтовано необхідність зміни статусу ЦМЗСУ і перейменування його у НВIМУ, як єдиного в Україні військово-історичного музею, що відображав би всі історичні етапи виникнення і розвитку військової справи й воєнного мистецтва 3 найдавніших часів до сьогодення. Над Концепцією працювали начальник музею, на той час полковник В. Карпов,а також доктори історичних наук М. Карпенко, В. Зубар і провідні співробітники музею полковник І. Чичкань, підполковник О. Скрябін. У 2009 році В. Карпов опублікував «Комплексну програму перспективного розвитку філій ЦМЗСУ», а у 2010 році, на честь отримання музеєм статусу «Національний», - історичну розвідку «100 років 3 дня створення першого військово-історичного музею в Україні». У цьому науковому дослідженні було викладено факти про діяльність військово-історичних музеїв і товариств 3 початку ХХ століття до часу створення МЗСУ, а потім ЦМЗСУ і НВIMУ [група 1 додатка 1].

Крім того, на шпальтах друкованого видання НВIМУ «Військовий музей», висвітлено звіти про його діяльність у період з 2000 по 2008 роки. Над упорядкуванням цих документів працювали В. Карпов (2000-2003 рр.), О. Скрябін (2004-2007 рp.), I. Мороз (2008 р.) [група 2 додатка 1]. Водночас, участь HВIMУ у міжвідомчих і міжнародних заходах в своїх наукових працях описали В. Карпов, О. Корнієнко, Н. Седак, О. Скрябін, I. Чичкань, О. Уткін [група 3 додатка 1]. При цьому, роботу виставок і фотовиставок висвітлили Л. Баята, І. Єфімова, Т. Іонова, 
Н. Седак, І. Чичкань. Натомість, I. Чичкань і Л. Баята, у співавторстві, підготували «Концепцію експозиції ЦМЗСУ «Збройні Сили України. Створення, реформування, розвиток (1991-2004 рр.)» [група 4 додатка 1].

Разом із тим, історію формування фондової колекції ЦМЗСУ (НВІМУ) можна прослідкувати за науковими статтями Ж. Денисюк, В. Давидюк, О. Срощенко, С. Петренко, С. Руденко, Б. Кучинського, I. Мороз, В. Горєлова, Н. Курсаніної, Л. Міненко, К. Ляшенко, О. Корнієнко, Д. Слободинського. У свою чергу, методику організації фондової роботи (у мережі військових музеїв ЗС України)розкрито у публікаціях Ж. Денисюк, В. Давидюк, Т. Бутко, С. Руденко. Особливості дослідження інформаційно-музейних технологій, як одного з головних напрямів діяльності музею, висвітлила Ю. Остапенко [групи 5, 6 додатка 1].

Методичне забезпечення організації роботи, у тому числі: проведення виставок, здійснення культурно-освітньої роботи, збереження документів і музейного зібрання, питання музейного менеджменту і маркетингу у мережі військових музеїв ЗС України охарактеризували О. Губченко, І. Єфімова, Н. Седак, Ю. Остапенко [група 7 додатка 1].

У досліджуваний період, не залишалася поза увагою і робота філій ЦМЗСУ (НВIMУ). Аналіз різних напрямів їх діяльності здійснювали як працівники головного музею 3С України, так і наукові співробітники філій. Зокрема, історію створення, проблеми функціонування, напрями і перспективи розвитку Волинського регіонального музею українського війська та військової техніки (ВРМУВВТ) описали В. Карпов, І. Сфімова, Н. Марищук, Я. Чисюк. Історію формування фондової колекції цієї філії дослідили В. Карпюк,
Н. Марищук, I. Пасюк, С. Соловський, О. Чичерська [група 8.1 додатка 1].

Специфіку діяльності та особливості фондозбірки Музею Ракетних військ стратегічного призначення в своїх наукових працях описали С. Бублик, М. Камєнсков, В. Ксензов, Т. Распаріна, Л. Тарасенко, О. Тарасенко. Крім того, робота зазначеної філії висвітлювалася в регіональних газетах і національних журналах. 3 метою зацікавлення експозицією музею потенційних відвідувачів, публікації мали ознайомлювально-рекламний характер. Музейний PR філії здійснювали журналісти Р. Росляк, Д. Тимчук, Є. Тищук [група 8.2 додатка 1].

Роботу філії НВІМУ- Військово-морський музейний комплекс «Балаклава» (ВММК «Балаклава»), наукові заходи, що проходили на їі базі, а також напрями розвитку експозиції висвітлювали Т. Веселюк, М. Левченко, I. Чичкань. Зміст фондів ВММК «Балаклава» охарактеризували О. Архангельська-Зав'ялова, Р. Баженов, Є. Бержицька, Я. Іванов, К. Ляховська, М. Троцак. Про перспективи розвитку південної філії музею у своїх інтерв'ю розповіли начальник НВІМУ В. Карпов і,на той час, директор філії В. Садовніченко. Музейний PR філії здійснювали журналісти М. Свграшина, Е. Озерян, М. Семена, Я. Турич, О. Щербаков [група 8.3 додатка $1]$.

Після приєднання до складу ЦМЗСУ ще однієї кримської філії у м. Севастополі - Військово-морського музею України, у наукових виданнях вийшли публікації В. Горєлова і В. Карпова, в яких було розкрито історію і шляхи подальшого розвитку цієї регіональної філії [група 8.4 додатка 1].

У 2010 році відбулося включення до складу НВІМУ двох філій: Меморіального комплексу «Пам'яті Героїв Крут» (Чернігівська обл.) і Музею «Герої Дніпра» 
(м. Івано-Франківськ). Історію створення та особливості формування фондової збірки Меморіального комплексу «Пам'яті Героїв Крут» у наукових статтях означили В. Сарана, Н. Примушко, а Меморіального комплексу «Пам'яті Героїв Крут»Я. Кваснюк [групи 8.5, 8.6 додатка 1].

В цілому, місце і роль військових музеїв у збереженні військово-історичної спадщини в своїх науковим працях визначили представники керівного складу 3С України Б. Андресюк і В. Діброва, а специфіку діяльності проаналізували T. Веселюк, І. Чичкань, М. Куліш, І. Непота, О. Скрябін, І. Тищенко, А. Хомович [групи 9, 10 додатка 1]. Разом із тим, керівники і провідні фахівці діючих військових музеїв України конкретизували особливості функціонування своїх установ. Так, В. Дерновий поінформував громадськість про історичні аспекти розвитку Військово-історичного музею Повітряних Сил 3С України. Р. Михайловський і А. Глушко висвітлили роботу Музею Харківського університету Повітряних сил ім. Івана Кожедуба. У свою чергу, В. Москаленко охарактеризував діяльність Військово-історичного комплексу «Скеля» у місті Коростені Житомирської області, а С. Паліса ознайомив з роботою Воєнно-історичного музею 58-го Будинку офіцерів. В. Фоміна описала відображення образу противника у головній експозиції, на той час, Меморіальному комплексі «Національний музей історії Великої Вітчизняної війни1941-1945 років» [група 10 додатка 1].

Натомість, співробітники ЦМЗСУ I. Єфімова, І. Колєснік, В. Лазебник (працівники Головного управління виховної роботи Міністерства оборони України), Ю. Остапенко, Н. Седак здійснили поетапний аналіз роботи військових музеїв ЗС України у 2003, 2007 і 2008 роках. 3 іншого боку, відомі історики-краєзнавці і меценати Д. Малаков, С. Ромадін, О. Шереметьєв, під своїм кутом зору, провели фаховий опис музейних предметів 3 приватних колекцій, та окреслили власне бачення головних аспектів військово-музейної справи в Україні [групи 11, 12 додатка $1]$.

Водночас, історію НВІМУ досліджували й інші науковці, не $з$ числа працівників музею. Так, військовий музеєзнавець В. Котвіцький, в одноосібній статті, охарактеризував основні проблеми утворення i розвитку музейних інституцій у Збройних Силах України (у період з 1991 по 1996 роки). Зокрема, автор відмітив вагому роль в створенні ЦМЗСУ Головного управління виховної роботи МО України. Стисло описав початковий етап діяльності майбутнього НВIMУ у зазначені роки,наголосив про вагомий вклад фахівців ЦМЗСУ у науково-методичне забезпечення розбудови системи військових музейних інституцій України,концептуально визначив стратегічні напрями роботи музею того періоду, а саме: культурно-освітній, науково-дослідний, експозиційний, фондовий, видавничий, бібліотечний та архівний [7].

Військовий фахівець В. Машталір у своїх працях військово-історичні споруди XIX-XX століть як об'єкти культурної спадщини України, здійснив дослідження інженерних військових об'єктів та висвітлив їх значення в розвитку військово-історичних музеїв. При цьому концептуально розглянув науково-дослідну, культурно-просвітницьку та експозиційну роботу НВIМУ. Станом на серпень місяць 2013 року, стисло охарактеризував роботу двох філій НВIMУ (Музей Ракетних військ стратегічного призначення і Центральний військово-морський музей України у м. Севастополі) та інших військово-історичних музеїв України [8]. У своїй док- 
торській дисертації «Генезис військово-історичного музейництва в Україні (кінець XIX - початок XXI століть)» В. Машталір досить широко розглянув мережу військових музеїв 3С України, визначив основні етапи становлення i розвитку військово-історичних музеїв України. Здійснив систематизацію закладів сучасної військово-історичної музейної мережі, розробив класифікацію державних музеїв у системі Міністерства оборони України, при навчальних закладах сфери управління Міністерства освіти і науки України, дослідив співвідношення військово-історичних та інших музеїв України. На основі статистичних даних, що збирали співробітники НВIМУ, здійснюючи науково-методичне керівництво військовими музеями Збройних Сил, науковець висвітлив кількісні показники роботи військової музейної мережі у 2003-2014 роках. В. Машталір запропонував концептуальні засади розвитку військових (відомчих) музеїв, деталізував напрями діяльності НВIMУ згідно його Статуту. Конспективно описав науково-методичну, видавничу діяльність та, з 1996 по 1998 роки - експозиційно-виставкову діяльність головної музейної установи Міністерства оборони України. При цьому акцентував увагу на ролі НВІМУ в створенні нормативно-правової бази для ефективного проведення військово-музейної справи [9].

У 2011 році, під керівництвом військового фахівця А. Кобзаря колектив авторів (Б. Андресюк, В. Безбах, А. Бережний, С. Василенко, В. Вилко, В. Горєлов, В. Грицюк, О. Демчучен, В. Дикун, Я. Зоpiй, В. Карпов, С. Катаєв, О. Копаниця, Ю. Красильник, А. Луценко, В. Малюга, В. Марценківський, В. Мулява, Л. Олійник, В. ашинський, О. Позняков, М. Ротань, В. Стасюк, С. Талаур, В. Філіпов, В. Чабаненко) підготували і випустили підручник, що розкривав теоретико-методологічні аспекти виховної роботи і військово-соціального управління у ЗС України. У цій науковій праці, в розділі, присвяченому військово-патріотичному вихованню, В. Карповим і В. Горєловим розглянуто місце й роль військових музеїв у військово-патріотичному вихованні військовослужбовців і молодого покоління [2].

Постановка завдання. Проаналізовані наявні наукові дослідження і публікації щодо становлення й розвитку мережі військових музеїв дають можливість мати певну уяву про окремі елементи бажаної системи виховної і соціально-психологічної роботи у ЗС України, місце НВIМУ у цій справі. Водночас варто зауважити, що інформація, більшою мірою, подана як науково-популярна і статистично-аналітична, без історично-наукової адаптації. У розглянутих наукових матеріалах тема формування мережі військових музеїв висвітлювалася, але діяльність безпосередньо музейного комплексу HBIMУ представлена не повно. Зокрема, достатньо малочисельними і мало інформативними $\epsilon$ публікації про діяльність філій головного музею ЗС України, а саме у період з 1995 року по 2013 рік.

3 метою упорядкування і змістовного доповнення наявної інформації про особливості формування й перспективи розвитку мережі військових музеїв ЗС України,як складової в системі виховної соціально-психологічної роботи у ЗС України (1995-2013 рр.), передбачено вирішити наступні завдання:

- охарактеризувати стан мережі військових музеїв Міністерства оборони України;

- визначити місце i роль НВІМУ та його філій у цій структурі станом на 31 грудня 2013 року. 
Виклад основного матеріалу. Здійснений аналіз публікацій про діяльність мережі військових музеїв у системі ЗС України у період з 1995 по 2013 роки показав, що досліджувана тема $є$ достатньо актуальною. Водночас значний масив існуючої інформації про військові музеї потребує змістовної систематизації, а також осмисленої візуалізації. Крім того опрацьований обсяг наукової інформації,що міститься у звітних та аналітичних документах про роботу філій НВІМУ вимагає проведення додаткових досліджень. Саме тому, для об'єктивної оцінки місця і ролі військових музеїв в цілому і HBIMУ та його філій зокрема в системі виховної і соціально-психологічної роботи департаментів гуманітарної політики, військово-медичного, військової освіти і науки Міністерства оборони України, а також Генерального штабу та Управління розвідки ЗС України, представимо всіх учасників цих процесів та їх взаємозв'язки у вигляді схеми (рuc. 1).

Візуалізація мережі військових музеїв у структурі Міністерства оборони України, Генерального штабу та Управління розвідки дозволяє побачити весь перелік структурних одиниць, що, станом на 31 грудня 2014 року, були задіяні для забезпечення виховної і соціально-психологічної роботи у ЗС України. Зауважимо, що завдяки широкій географії розташування і диференційованій музейній спеціалізації аксіологічно-патріотичний вплив здійснювався не лише на свідомість військовослужбовців, а й на членів їхніх родин та інших громадян, які відвідували відображені на рисунку просвітницькі заклади культури. Джерелом інформації для побудови схеми став «Аналіз підсумків роботи військових музеїв (музейних утворень) Збройних Сил України» за різні роки [1, група 11 додатку 1].

У досліджуваний період, діяльність військових музеїв у ЗС України регламен- тувалася вимогами Наказу Міністра оборони України від 06 березня 2002 року № 95 «Про затвердження Положенням про організацію діяльності військових музеїв та музеїв (кімнат) бойової (трудової) слави у Збройних Силах України» (Наказ МО України від 06 березня 2002 року № 95) [13]. У свою чергу, за певних об'єктивних обставин, Наказ Міністра оборони України від 17 липня 2018 року № 343 «Про затвердження Положенням про організацію діяльності військових музеїв, музеїв (кімнат) бойових традицій у Збройних Силах України» чинності не набув. У зв'язку 3 цим НВIMУ продовжував дотримуватися норм Наказу МО України від 06 березня 2002 року № 95 [14]. 10 липня 2019 року набрав чинності Наказ МО України № 374 «Про затвердження Інструкції 3 організації діяльності військових музеїв, музеїв (кімнат) бойових традицій у Збройних Силах України», нормами якого сьогодні керуються всі військові музеї ЗС України [12]. Так як період нашого дослідження 1995-2013 роки, відповідно, ми будемо використовувати встановлені терміни і посилатимемося на Наказ МО України від 06 березня 2002 року № 95.

В усіх Наказах Міністра оборони України та всіма нормативними актами визначено роль Національного військово-історичного музею України як головного щодо інших музеїв й зобов'язано його сприяти розвитку і науково-методичній постановці музейної справи у ЗС України. Отже, з 2002 року НВІМУ (тоді ЦМЗСУ) почав здійснювати науково-методичне керівництво музеями й кімнатами бойової і трудової слави ЗС України. 3 часу заснування НВІМУ (1995 рік) до 2002 року відбувалося напрацювання відповідних ресурсів, що і дозволило фахівцям цієї установи, у стислі терміни, централізовано упорядкувати діяльність музейної мережі ЗС України. 


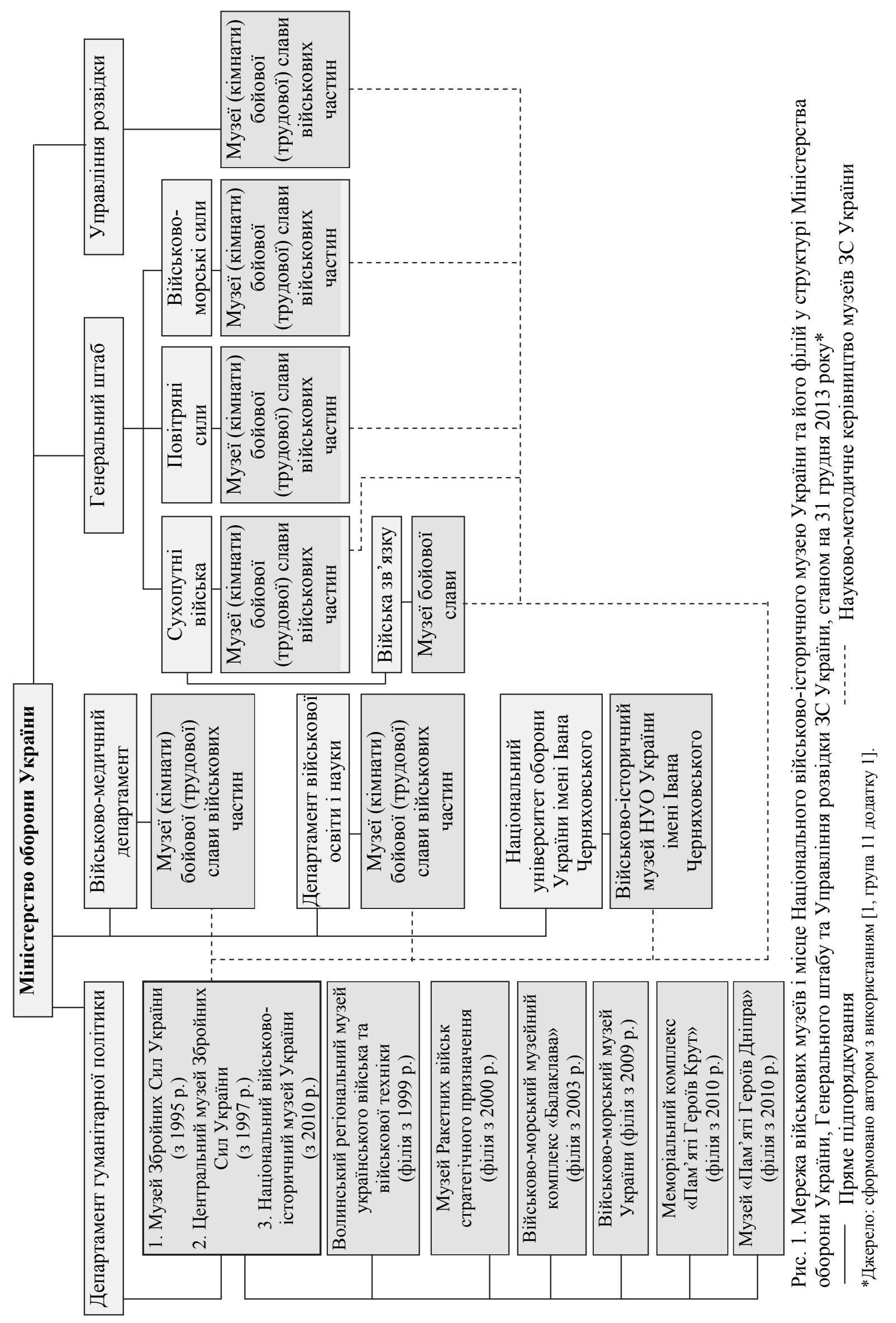


Передумови та історія військового музейного руху з початку ХХ століття докладно висвітлені у роботах В. Карпова $[6,4]$. Станом на 1995 рік основою причиною створення нових і впорядкування існуючих військових музеїв ЗС України стало проголошення незалежності України в 1991 році. Це був період трансгресії суспільства, що тривав з 1989 року, коли Україна, в умовах перебудови і гласності в СРСР,почала рух до виходу з його складу [5]. На перетині епох, силами малочисельного колективу на чолі з 32-річним керівником Музею 3С України, тоді майором Віктором Карповим, в 1995 році, в умовах державної кризи і відсутності належних ресурсів,започатковувалося створення і розбудова потужного системного наукового центру по дослідженню воєнної історії України. Згодом, із одного музею у м. Києві розрослася мережа військових музеїв ЗС України (рис. 1) [11]. Вона органічно стала основою для побудови системи виховної і соціально-психологічної роботи у ЗС України, головним державним інструментом аксіологічно-патріотичного виховання. Мережа військових музеїв ЗС України забезпечувала цілісність і належне функціонування вказаної системи та виконувала поставлені керівництвом, під впливом історичних умов, завдання. Саме Наказ МО України від 06 березня 2002 року № 95 став нормативною основою для формування вказаної системи та іiї стабільно-цілеспрямованої роботи.

Цим наказом було започатковано досить широкий спектр діяльності військових музеїв (музейних утворень). Зокрема, передбачалися наступні профілі (види) військових музеїв ЗС України: історичні, технічні, літературні, художні, архітектурні тощо. Крім того визначалися типи музеїв, тобто їхнє суспільне призначення та основні цілі функціонування, а саме [13]:
— науково-просвітницький (найпоширеніший тип музеїв, що у своїй роботі здійснюють освітні і виховні цілі й зорієнтовані на масового відвідувача);

- академічний (музеї, зорієнтовані в основному на спеціалістів, в яких використання музейного фонду здійснюється головним чином у дослідницьких цілях);

- навчального типу(музеї, зорієнтовані перш за все на виконання завдань навчальних програм і педагогічних методик).

На практиці, основу музейної мережі 3С України склали військові музеї (музейні утворення) історичного виду і науково-просвітницького типу. Основними задачами військових музеїв (музейних утворень) визначалося документування:

- історії воєн, військового мистецтва, будівництва ЗС України, зброї, військової техніки, обмундирування, спорядження і знаків розрізнення, військової думки;

- бойового (трудового) шляху військових частин, установ та організацій;

- життєвого шляху і діяльності визначних воєначальників, національних героїв, заслужених діячів в області військової науки, техніки і технологій.

Налагодження комунікацій в середині мережі військових музеїв ЗС України відбувалося завдяки широкому спектру міжмузейних зв'язків. Центром цього процесу, як вже зазначалося, був ЦМЗСУ (HВIMУ). Під його науково-методичним керівництвом перебували головні військові музеї (музейні утворення) видів 3С України, оперативних командувань. Останні, в свою чергу, координували роботу військових музеїв (музейних утворень) наявних у підпорядкуванні підрозділів 3С України.

Координація з боку ЦМЗСУ (НВIМУ) науково-методичної роботи військових музеїв (музейних утворень) видів 3С України та організовані заходи щодо надання допо- 
моги військовим музеям (музейним утворенням) передбачали [13]:

- налагодження, згідно чинного законодавства, основних напрямів музейної діяльності;

— вивчення досвіду роботи зарубіжних військових музеїв;

- обмін досвідом роботи на національному рівні;

- спільна участь в обговоренні й створенні експозицій і виставок у військових музеях (музейних утвореннях) видів Збройних Сил України, оперативних командуваннях;

- надання методичної допомоги військовим музеям (музейним утворенням), координація їх взаємодії, пропагування досвіду їх роботи;

- проведення консультацій представникам військового командування з питань створення і практичної діяльності військових музеїв (музейних утворень);

- здійснення консультативної допомоги іншим музеям України з питань експозиційної, культурно-просвітницької і фондової роботи, пов'язаних 3 військовою проблематикою;

- підготовка концептуальних положень щодо розвитку музейної справи України у військово-історичній сфері;

- проведення стажування, методичних семінарів, інших заходів для підвищення кваліфікації керівних і наукових працівників військових музеїв (музейних утворень);

- ведення обліку основних показників діяльності військових музеїв (музейних утворень) у ЗС України.

Згідно Наказу МО України від 06 березня 2002 року № 95 професійне навчання працівників військових музеїв (музейних утворень) Головного управління виховної роботи МО України (ГУВР МО України) проводилося під час навчально-методичних зборів і семінарів. 3 метою підвищення рів- ня фахової підготовки працівників військових музеїв (музейних утворень) ГУВР МО України один раз на два роки організовував і проводив стажування у військах (силах). У межах цих навчань ЦМЗСУ (НВIMУ) проводив навчально-методичні заняття на своїй базі. Так, починаючи з 2002 року,було проведено ряд різнопланових методично-координуючих і науково-просвітницьких заходів, а саме [3 (2003, 2004, 2006, 2007, 2012), група 11 додатку 1]:

- науково-практична конференція «Організація діяльності, напрямки й перспективи розвитку військових музеїв та музеїв (кімнат) бойової (трудової) слави у Збройних Силах України» (травень 2002 року);

— конференція-круглий стіл «Проблеми розвитку воєнно-історичної науки в сучасних умовах» (червень 2003 року);

- науково-практичний семінар «Ocновні проблеми діяльності Центрального музею Збройних Сил України» (грудень 2004 року);

- Всеукраїнська науково-практична конференція «Український технічний музей: історія, досвід, перспективи» (травень 2006 і 2012 років);

- науково-практичний семінар «Проблеми науково-дослідної роботи в Центральному музеї Збройних Сил України» (січень 2006 року);

- навчально-методичний семінар «Методика планування та організація проведення в позаурочний час заходів 3 військово-патріотичного виховання шкільної молоді» (грудень 2006 року);

- семінар «Патріотичне виховання молоді у шкільний і позашкільний час» (жовтень 2007 року);

- науково-практичний семінар «Музейна справа в Україні. Військовий аспект» (січень 2007 року);

- науково-практичний семінар «Актуальні проблеми розвитку символіки 
у Збройних Силах та інших військових формуваннях України» (2008 рік);

— науково-практичний семінар «Діяльність Центрального музею Збройних Сил України як головного військового музею в дослідженні і збереженні пам'яток військової історії України» (січень 2009 року).

Надалі науково-практичні зібрання організовувалися у формі конференцій, де обговорювалися основні тенденції і проблеми у галузі військової музейної справи, визначалися концептуальні засади і напрями подальшої роботи. Так,починаючи з 2010 року, враховуючи досвід філій НВІМУ, виносилися на публічне обговорення проблеми розвитку військових музейних утворень, проводився відкритий аналіз їх позитивних практичних результатів. Цьому були присвячені [3 (2010, 2011)]:

- науково-практична конференція «Діяльність військово-історичних музеїв у сучасному культурно-інформаційному просторі» (25 лютого 2010 року, м. Київ);

- науково-практична конференція «Актуальні проблеми національної безпеки та шляхи їх вирішення» (20 грудня 2011 року, м. Київ).

Важливим досягненням музейного просвітництва стало започаткування (з 2009 року) циклу досліджень військової історії регіонів України. Цикл наукових конференцій і видання за їх результатами збірників наукових матеріалів був запланований в розрізі виконання Програми військово-патріотичного виховання у ЗС України на 2008-2011 роки, затвердженої 09 липня 2008 року № 340 [15]. Враховуючи виняткову роль історії регіонів в розвитку вітчизняної військової науки, конференції несли загальнодержавне значення і військово-патріотичне виховання відбувалося не лише у лавах 3С України, а й серед усіх заінтересованих науков- ців, музейних працівників, державних службовців тощо. Як підсумок, $з 2009$ по 2013 роки, ЦМЗСУ, а з 2010 року, Національним військово-історичним музеєм України, було організовано, проведено і видано збірники таких конференцій [3 (2009, 2010, 2011, 2012, 2013)]:

- Всеукраїнська історико-краєзнавча наукова конференція «Минуле і сучасне Волині та Полісся. Сторінки воєнної історії краю» (25 березня 2009 року, м. Луцьк);

- Всеукраїнська наукова військово-історична конференція «Воєнна історія Поділля та Буковини» (26 листопада 2009 року, м. Кам'янець-Подільський);

- Всеукраїнська наукова військово-історична конференція «Воєнна історія Галичини та Закарпаття» (15 квітня 2010 року, м. Львів);

- Всеукраїнська наукова військово-історична конференція «Воєнна історія Сіверщини та Слобожанщини» (15 грудня 2010 року, м. Харків);

- Міжнародна наукова конференція «Україна у Другій світовій війні: джерела та інтерпретації» спільно з Меморіальним комплексом «Національний музей історії Великої Вітчизняної війни 1941-1945 років» (27 квітня 2010 року, м. Київ);

- Всеукраїнська наукова військово-історична конференція «Воєнна історія Наддніпрянщини та Донщини» (25 травня 2011 року, м. Дніпропетровськ);

- Всеукраїнська наукова військово-історична конференція «Воєнна історія Північного Причорномор'я і Таврії» $(6,7$ жовтня 2011 року, м. Севастополь);

- Всеукраїнська наукова військово-історична конференція «Воєнна історія Середньої Наддніпрянщини» (15 березня 2012 року, м. Київ);

- Міжнародна наукова військово-історична конференція «Холодна війна»: істо- 
рія та уроки (1946-1991рр.)» (4, 5 жовтня 2012 року, м. Севастополь);

- Всеукраїнська наукова військово-історична конференція «Воєнна історія України. Регіони Волинь та Полісся» (25, 26 квітня 2013 року, м. Рівне);

- Міжнародна наукова військово-історична конференція «Кримська війна»: історія та уроки (1853-1856 рр.)» (27, 28 вересня 2013 року, м. Севастополь).

Проводячи заходи всеукраїнського і міжнародного рівня, НВIMУ забезпечував стратегічний напрям державного патріотичного i військово-патріотичного виховання по всій території України, фахово виступав головним науково-методичним координатором у мережі військових музеїв ЗС України,виконував норми Програми військово-патріотичного виховання у 3С України на 2008-2011 роки [15]. Такий науковий, зокрема, військово-історичний туризм, був складовою системи виховної і соціально-психологічної роботи у ЗС України. Він служив дієвим інструментом впливу і формував національні інтереси у науковців-учасників, працівників НВIMУ, у керівного і рядового складу 3С України. При цьому виконувалася функція розвиваючого дозвілля, що консолідувало учасників різних соціальних верств і регіонів, нівелювало регіональні відмінності й стереотипи, формувало загальноукраїнську ідентичність $\mathrm{i}$, саме головне, - позитивний імідж $3 \mathrm{C}$ України і нашої держави. Що найцінніше, за допомогою проведення саме військово-історичних конференцій на базі НВIMУ, серед науковців-істориків відбувалася популяризація досліджень саме на військово-історичну тематику. Фактично це було фахово-цілеспрямоване занурення у середовище військової історії всіх небайдужих, хто бажав отримати відповіді на проблемні питання.
Варто також зазначити, що за вимогою Наказу МО України від 06 березня 2002 року № 95, військові музеї (музейні утворення) 3С України до 20 січня поточного року повинні були подавати звіти про підсумки своєї річної діяльності в органи виховної роботи за їх підлеглістю, а копії - до ЦМЗСУ (НВІМУ). Натомість фахівці головного музею мали здійснювати аналіз надісланих матеріалів 3 метою відображення загального стану справ у військово-музейній галузі $[1,13]$. Саме тому, 30 травня 2002 року на базі ЦМЗСУ було проведено науково-практичну конференцію, на якій окреслено нові завдання і визначено загальну мету співпраці, а саме:

- впорядкувати діяльність військово-музейних установ у ЗС України;

- підвищити роль музеїв у військово-патріотичному вихованні;

- зберегти і використати пам'ятки матеріальної культури у військовій сфері;

- зробити доступними, цікавими і зрозумілими надбання військової національної та історико-культурної спадщини нашої держави для особового складу ЗС і громадян України.

Дякуючи такій організованій координації, ЦМЗСУ (НВIMУ), починаючи з 2003 року, розпочав здійснювати статистичний облік даних і проводити науково-методичний аналіз діяльності військових музеїв (музейних утворень) структурних підрозділів 3С України. Для систематизованого обліку фахівці музею розробили бланки статистичної звітності завдяки яким щорічно спостерігали та аналізували стан справ у військово-музейній галузі ЗС України [1, група 11 додатку 1]. Такий плановий збір інформації відбувався до 2013 року.

Починаючи з кінця 2013 року - початку 2014 року, суспільно-політичні події у нашій державі (Революція Гідності, анексія АР Крим і воєнні дії на сході 
України) завадили вчасно подати звіти до НВIMУ про діяльність військових музеїв і музеїв (кімнат) бойової (трудової) слави у Сухопутних військах, Повітряних Силах i Військово-Морських Силах Збройних Сил України (за 2013 рік із 73 музеїв прозвітувало лише 48) [1 (2013)]. За умов, що склалися, і у зв'язку з неналежним відношенням до цього надзвичайно важливого напряму роботи з боку нового керівництва HВIMУ і тодішнього керівництва Міністерства оборони України, систематизований збір статистичної інформації про діяльність музейний установ ЗС України було призупинено. Саме тому, у нашому дослідженні ми обмежилися даними, отриманими до 2012 року включно. Попри все, зібрані і проаналізовані дані у 2003 і 2012 році переконливо демонструють суттєве покращення діяльності мережі військових музеїв (музейних утворень) 3С України за досліджуваний період (табл. 1).

Водночас, для повноцінного аналізу, надзвичайно вагомими у діяльності музейних установ $є$ дані показників по структурі основних фондів (ОФ) і науково-допоміжних фондів (НДФ) (табл. 2). А також дані, що характеризують результати культурно освітньої роботи (табл. 3). Візуально побачити внесок структурних підрозділів 3С України у розвиток загальної військової музейної мережі пропонуємо на основі даних відображених на рис. 2 і рис. 3.

Зазначені у таблицях 2, 3 і візуалізовані на рис. 2, 3 дані фіксують проміжні підсумки роботи музеїв і кімнат бойової (трудової) слави в структурі Міністерства оборони України, Генерального штабу та Управління розвідки ЗС України станом на 31 грудня 2012 року.

\section{УЗАГАЛЬНЕНЕ ПОРІВНЯННЯ ПОКАЗНИКІВ ДІЯЛЬНОСТІ МЕРЕЖІ ВІЙСЬКОВИХ МУЗЕЇВ (МУЗЕЙНИХ УТВОРЕНЬ) ЗС УКРАЇНИ за 2003 і 2012 рік*}

\begin{tabular}{|c|c|c|c|c|c|c|c|}
\hline \multirow{2}{*}{ Рік } & \multirow{2}{*}{$\begin{array}{c}\text { Загальна } \\
\text { кіл-ть } \\
\text { музеїв }\end{array}$} & \multirow{2}{*}{$\begin{array}{c}\text { Загальна } \\
\text { кіл-ть } \\
\text { предметів } \\
\text { ОФ } \\
\text { і НДФ (од.) }\end{array}$} & \multicolumn{2}{|c|}{$\begin{array}{c}\text { Загальна кількість } \\
\text { відвідувачів (осіб) }\end{array}$} & \multirow{2}{*}{$\begin{array}{c}\text { Кіл-ть } \\
\text { екскурсій }\end{array}$} & \multicolumn{2}{|c|}{$\begin{array}{c}\text { Обслуговано } \\
\text { екскурсіями } \\
\text { (осіб) }\end{array}$} \\
\hline & & & Усього & $\mathbf{Y}_{\text {T.Ч. В/c }}$ & & Усього & У т.ч. в/с \\
\hline 2003 & 66 & 42717 & 112220 & 50371 & 5480 & 62408 & 43896 \\
\hline 2012 & 73 & 123097 & 272890 & 47206 & 9982 & 190777 & 129193 \\
\hline
\end{tabular}

* Джерело: сформовано автором на основі [1, група 11 дод. 1]. 
Таблиия 2

\section{СТРУКТУРА ФОНДІВ ВІЙСЬКОВИХ МУЗЕЇВ (МУЗЕЙНИХ УТВОРЕНЬ) ЗС УКРАЇНИ СТАНОМ НА 31.12.2012 року*}

\begin{tabular}{|c|c|c|c|c|c|c|c|c|c|}
\hline \multirow[b]{2}{*}{$\begin{array}{l}\text { № } \\
\text { п/II }\end{array}$} & \multirow{2}{*}{$\begin{array}{l}\text { Назва музею, } \\
\text { кімнати бойової } \\
\text { (трудової) слави }\end{array}$} & \multirow{2}{*}{$\begin{array}{c}\text { Кіл-ть } \\
\text { предметів } \\
\text { ОФ }\end{array}$} & \multicolumn{6}{|c|}{ Типи предметів основного фонду музею } & \multirow{2}{*}{$\begin{array}{c}\text { Кіл-ть } \\
\text { предметік } \\
\text { НДФ }\end{array}$} \\
\hline & & & $\begin{array}{l}\text { Предмети } \\
\text { озбросння } \\
\text { та техніки }\end{array}$ & Речові & $\begin{array}{l}\text { Образо- } \\
\text { творчі }\end{array}$ & $\begin{array}{l}\text { Доку- } \\
\text { мен- } \\
\text { тальні }\end{array}$ & Фото & $\begin{array}{c}\text { Кіно } \\
\text { та } \\
\text { відео }\end{array}$ & \\
\hline 1. & $\begin{array}{l}\text { Сухопутні війська } \\
\text { ЗС України }\end{array}$ & 4832 & 528 & 1382 & 180 & 523 & 2201 & 18 & 4776 \\
\hline 2. & $\begin{array}{l}\text { Повітряні Сили } \\
\text { ЗС України }\end{array}$ & 6105 & 1564 & 1381 & 211 & 949 & 1950 & 50 & 1955 \\
\hline 3. & $\begin{array}{l}\text { Військово-морські } \\
\text { Сили ЗС України }\end{array}$ & 1301 & 109 & 95 & 164 & 139 & 784 & 10 & 2020 \\
\hline 4. & $\begin{array}{l}\text { Головне управління } \\
\text { розвідки МО України }\end{array}$ & 1046 & 171 & 564 & 35 & 150 & 114 & 12 & 505 \\
\hline 5. & $\begin{array}{l}\text { Військово-медичний } \\
\text { департамент } \\
\text { МО України }\end{array}$ & 1403 & - & 389 & 154 & 327 & 490 & 43 & 182 \\
\hline 6. & \begin{tabular}{|l} 
Департамент \\
військової освіти \\
та науки МО України \\
\end{tabular} & 2713 & 48 & 25 & 68 & 327 & 2230 & 15 & 228 \\
\hline 7. & $\begin{array}{l}\text { Національний } \\
\text { університет оборони } \\
\text { України ім. Івана } \\
\text { Черняховського }^{1}\end{array}$ & 883 & 93 & - & 157 & $68^{2}$ & 565 & - & 29 \\
\hline 8. & $\begin{array}{l}\text { Війська зв’язку } \\
\text { 3С України }\end{array}$ & 758 & 221 & 111 & 27 & 189 & 208 & 2 & 148 \\
\hline 9. & $\begin{array}{l}\text { Головне управління } \\
\text { по роботі з особовим } \\
\text { складом ЗС України }\end{array}$ & 296 & 119 & 115 & 58 & 4 & - & - & - \\
\hline 10. & $\begin{array}{l}\text { Національний } \\
\text { військово-історичний } \\
\text { музей України } \\
\text { та його філії }\end{array}$ & 83684 & 52372 & 18263 & 336 & 4292 & 8336 & 85 & 10233 \\
\hline & Всього: & 103021 & 55225 & 22325 & 1390 & 6968 & 16878 & 235 & 20076 \\
\hline
\end{tabular}

* Джерело: сформовано автором на основі [1].

${ }^{1}$ Цитата 3 Аналізу підсумків роботи військових музеїв (музейних утворень) 3С України за 2012 рік: «фонди музею налічують 912, серед них 883 предметів основного фонду та 29 - науково-допоміжного. Протягом року до фондів музею надійшло 5 предметів основного фонду. У структурі предметів основного фонду переважають фотографії — 565 одиниць, образотворчі предмети 157 одиниць і предмети озброєння та техніки - 93 одиниці» [5 (2012)].

${ }^{2}$ Виконавець звіту вказав лише предмети основного фонду, що «переважають» (див. посилання 1), тому математично порахований залишок віднесемо до документального фонду (графа 7 табл. 2) для збереження математичного порядку таблиці. 
Таблиия 3

\section{ПОКАЗНИКИ КУЛЬТУРНО-ОСВІТНЬОЇ РОБОТИ ВІЙСЬКОВИХ МУЗЕЇВ (МУЗЕЙНИХ УТВОРЕНЬ) СТРУКТУРНИХ ПІДРОЗДІЛІВ ЗС УКРАЇНИ СТАНОМ НА 31.12.2012 року*}

\begin{tabular}{|c|c|c|c|c|c|c|c|}
\hline \multirow{2}{*}{$\begin{array}{l}\text { № } \\
\text { ПI/П }\end{array}$} & \multirow{2}{*}{$\begin{array}{l}\text { Назва музею, } \\
\text { кімнати бойової } \\
\text { (трудової) слави }\end{array}$} & \multicolumn{2}{|c|}{$\begin{array}{c}\text { Загальна кількість } \\
\text { відвідувачів (осіб) }\end{array}$} & \multirow{2}{*}{$\begin{array}{c}\text { Із них } \\
\text { обслуговано } \\
\text { екскурсіями } \\
\text { всього } \\
\text { (осіб) }\end{array}$} & \multicolumn{2}{|c|}{ У тому числі } & \multirow{2}{*}{$\begin{array}{l}\text { Кіль- } \\
\text { кість } \\
\text { екскур- } \\
\text { сій }\end{array}$} \\
\hline & & усього & $\begin{array}{l}\text { військово- } \\
\text { службовців }\end{array}$ & & $\begin{array}{l}\text { військово- } \\
\text { службовців }\end{array}$ & інших & \\
\hline 1. & $\begin{array}{l}\text { Сухопутні війська } \\
\text { ЗС України }\end{array}$ & 35629 & 12402 & 34450 & 12262 & 22188 & 1073 \\
\hline 2. & $\begin{array}{l}\text { Повітряні Сили } \\
\text { ЗС України }\end{array}$ & 45411 & 13836 & 30109 & 8163 & 21946 & 1350 \\
\hline 3. & $\begin{array}{l}\text { Військово-морські Сили ЗС } \\
\text { України }\end{array}$ & 8331 & 3540 & 3534 & 910 & 2624 & 90 \\
\hline 4. & $\begin{array}{l}\text { Головне управління } \\
\text { розвідки МО України }\end{array}$ & 1379 & 1063 & 905 & 156 & 749 & 70 \\
\hline 5. & $\begin{array}{l}\text { Військово-медичний } \\
\text { департамент МО України }\end{array}$ & 333 & 132 & 168 & 107 & 61 & 108 \\
\hline 6. & $\begin{array}{l}\text { Департамент військової } \\
\text { освіти та науки МО України }\end{array}$ & 3235 & 1451 & 3032 & 1025 & 2007 & 119 \\
\hline 7. & $\begin{array}{l}\text { Національний університет } \\
\text { оборони України } \\
\text { ім. Івана Черняховського }\end{array}$ & 3500 & 1800 & 2600 & 1700 & $900^{4}$ & 120 \\
\hline 8. & $\begin{array}{l}\text { Війська зв’язку } \\
\text { Збройних Сил України }\end{array}$ & 5650 & 1900 & 5650 & 1900 & 3750 & 240 \\
\hline 9. & $\begin{array}{l}\text { Головне управління } \\
\text { по роботі з особовим } \\
\text { складом ЗС України }\end{array}$ & 6486 & 3427 & 3243 & 1523 & 1720 & 229 \\
\hline 10. & $\begin{array}{l}\text { Національний військово- } \\
\text { історичний музей України } \\
\text { та його філії }\end{array}$ & 162936 & 7655 & 107086 & 101447 & 5639 & 6583 \\
\hline & Всього: & 272890 & 47206 & 190777 & 129193 & 61584 & 9982 \\
\hline
\end{tabular}

* Джерело: сформовано автором на основі [1].

${ }^{3}$ Цитата 3 Аналізу підсумків роботи військових музеїв (музейних утворень) ЗС України за 2012 рік: «Протягом року музей відвідало 3500 відвідувачів, 1800 з яких - військовослужбовці (51,4\% від кількості відвідувачів цього музею). Проведено 120 екскурсій, екскурсіями обслуговано 2600 чоловік, з них 1700 військовослужбовців» [1 (2012)].

${ }^{4}$ Відповідальні за підготовку звіту вказали лише загальну кількість чоловік, які обслуговані екскурсіями (див. посилання 3), тому математично порахований залишок віднесемо до «Інших» (графа 7 табл. 3) для збереження математичного порядку таблиці. 
Національннй військово-історичний музей Украӥнн та його філії

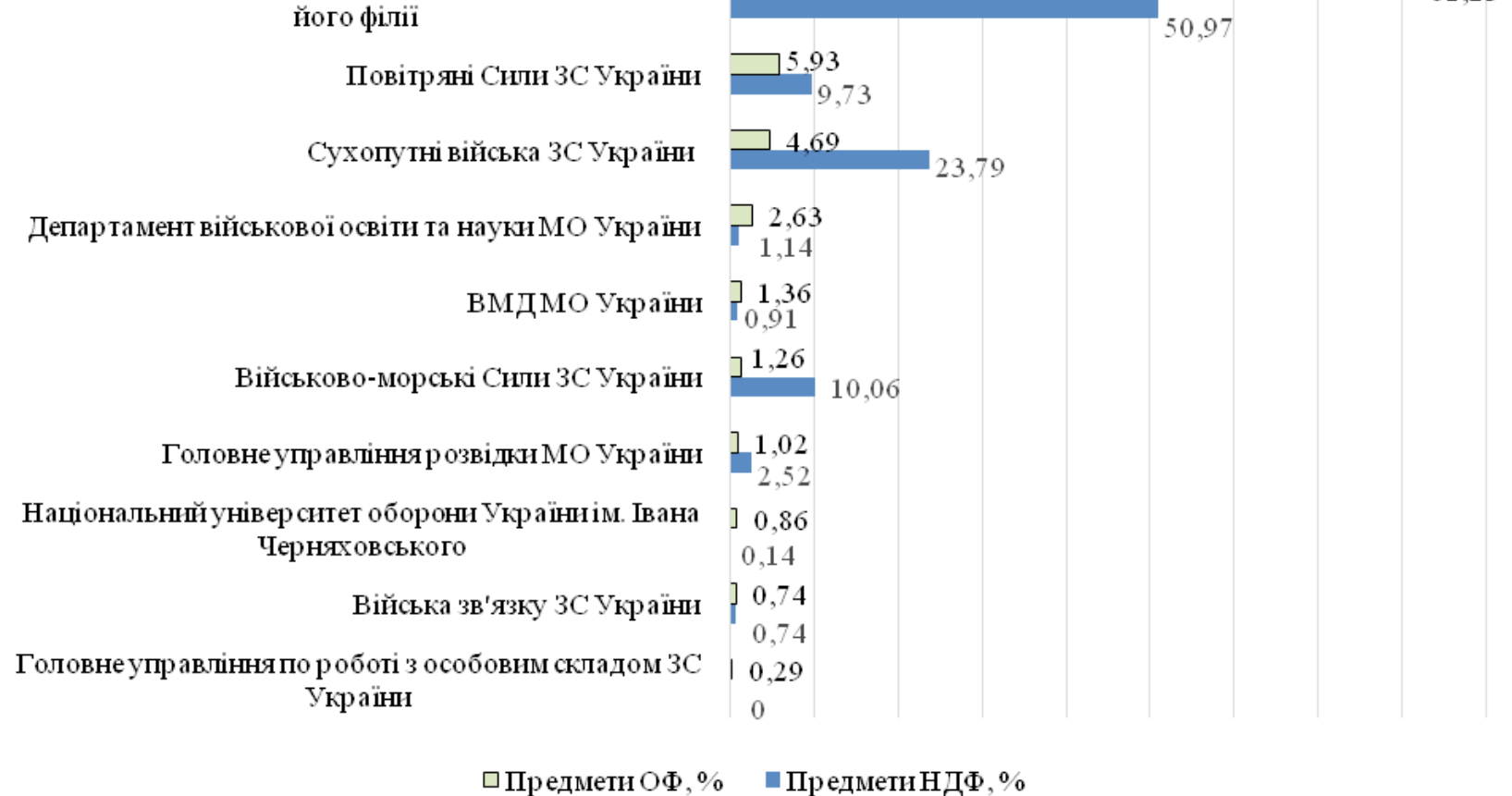

Рис. 2. Загальна структура фондів військових музеїв (музейних утворень)

3С України станом на 31.12.2012 p., \%*

* Джерело: сформовано автором на основі [1 $(2012,2013)]$.

Національний військово-історнчний музей Українн та його філіі

Головне управління по р оботі з особовим складом 3С України

Війська зв'язку Збр ойннх Сил Українн

Національнийунівер ситет оборонн Україннім. Івана Черняховського

Департамент військової освіти та наукн МО України

$$
\begin{aligned}
& \begin{array}{l|l}
\text { ВМдмО Українн } & 0,12 \\
0,28
\end{array} \\
& \text { Головне упр авління р озвідки МО України } \\
& \text { Військово-морські Сили ЗС України } \\
& \text { Повітряні Сили 3С Украӥнн } \\
& \text { Сухопутні війська ЗС України }
\end{aligned}
$$

Рис. 3. Загальна кількість відвідувачів військових музеїв (музейних утворень)

ЗС України станом на 31.12.2012 року, \%*

* Джерело: сформовано автором на основі [1 $(2012,2013)]$. 
Висновок. Досягнуті показники роботи дають можливість стверджувати, що військова музейна мережа за досліджуваний період, використовуючи адаптований до історичних умов відповідний механізм аксіологічного військово-патріотичного виховання, перетворилася у дієву систему взаємовідносин, що, станом на 31 грудня 2012 року, забезпечила належний рівень функціонування системи виховної і соціально-психологічної роботи ЗС України [10]. Сформована система хоча і передбачала ієрархічно централізоване підпорядкування $з$ дотриманням субординації, а іiі елементи мали єдині принципи побудови, по суті, достатньо фахово сприяла самостійності учасників як у взаємодії з іншими заінтересованими сторонами, так і в реалізації власної діяльності [16]. Головним координатором функціонування окремих елементів цієї системи, що здійснював науково-методичне керівництво і створював умови для ефективного іiі розвитку, виступав Національний військово-історичний музей України.

За будь-яких обставин, давати узагальнену оцінку роботи кожному музею (музейному утворенню) ЗС України,на нашу думку,є некоректно. Це пояснюється тим, що кожен з них мав різний кадровий склад, стан організаційного і ресурсного забезпечення, рівень науково-дослідної і методичної роботи, якість робочих місць тощо. Серед основних проблем були: обмежена чисельність фахівців, які працювали за штатним розписом;практично відсутність фахівців музейної справи; неналежне ресурсне та інформаційно-методичне забезпечення діяльності. Крім того,події, що відбулися і відбуваються у нашій державі, трансгресивні процеси в суспільстві і ЗС України, мали і мають значний вплив на діяльність військових музеїв (музейних утворень).

Попри все, розглядаючи, на основі статистичних звітів,період діяльності з 2003 року по 2013 рік, а саме період найвищої активності мережі військових музеїв (музейних утворень) 3С України, ми можемо констатувати високий рівень отриманих результатів. Найбільший внесок здійснено силами кадрового складу Національного військово-історичного музею України. 3окрема, на основі аналізу документальних фондів НВIМУ періоду 1995-2013 років, за допомогою статистичного методу, відтворено (зроблено реконструкцію) становлення і розвитку НВIMУ, як одного 3 активних учасників системи виховної і соціально-психологічної роботи ЗС України

Однак, цей порядок було порушено через трансгресивні події в Україні з кінця 2013 року. Значна кількість музеїв (музейних утворень) просто перестала діяти або ïx функціонування припинили фіксувати документально, або ж вони стали не центрами аксіологічно-патріотичного виховання, а кімнатами скорботи. Разом з тим, дві філії НВIMУ $з$ музейними фондами залишилися на території анексованої АР Крим. Незважаючи на обставини, що склалися, науковцям-історикам, особливо військовим належить плідно працювати над існуючим літописом розбудови вітчизняної армії,щоб трансформувати трагічні події, факти та їх учасників у приклади особистісної доблесті, звитяги, подвигу, жертовності, любові, моралі для підростаючого покоління і збереження національної пам’яті. 


\section{ГРУПУВАННЯ ПУБЛІКАЦІЙ ПРО НАЦІОНАЛЬНИЙ \\ ВІЙСЬКОВО-ІСТОРИЧНИЙ МУЗЕЙ УКРАЇНИ,
ФІЛІЇ ТА ВІЙСЬКОВІ МУЗЁ̈ У ПЕРІОД 2000 по 201

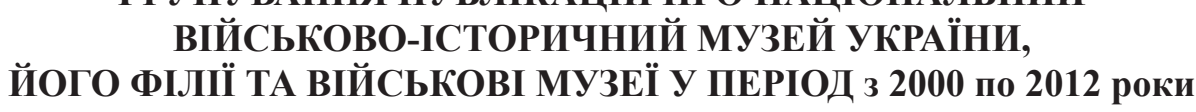

Групи публікацій / Назва статті

\begin{tabular}{|c|c|c|}
\hline & Групи публікацій / Назва статті & Видання \\
\hline 1. & \multicolumn{2}{|l|}{ Організація роботи ЦМЗСУ (НВІМУ) } \\
\hline 1.1. & Положення про музеї та музейну справу у ЗСУ (проект) & Військовий музей. № 1. 2000. С. 128-157 \\
\hline 1.2 . & Положення про ЦМЗСУ & Військовий музей. № 1. 2000. С. 158-167 \\
\hline 1.3. & Положення про фондово-закупівельну комісію ЦМЗСУ & Військовий музей. № 1. 2000. С. 168-170. \\
\hline 1.4 . & $\begin{array}{l}\text { Карпов В., Карпенко М., Зубар В., Чичкань І., Скрябін О. } \\
\text { Концепція НВІМУ }\end{array}$ & Військовий музей. № 7. 2006. С. 101-137 \\
\hline 1.5 . & $\begin{array}{l}\text { Карпов В. Комплексна програма перспективного розвит- } \\
\text { ку філій ЦМЗСУ }\end{array}$ & $\begin{array}{l}\text { Український військовий музей. № } 1 . \\
\text { 2009. С. 6-10 }\end{array}$ \\
\hline 1.6. & $\begin{array}{l}\text { Карпов В. } 100 \text { років з дня створення першого військо- } \\
\text { во-історичного музею в Україні }\end{array}$ & $\begin{array}{l}\text { Український військовий } \quad \text { музей. № } 2 . \\
\text { 2010. С. 4-7 }\end{array}$ \\
\hline 2. & \multicolumn{2}{|l|}{ Звіти про діяльність ЦМЗСУ з 2000 по 2008 роки } \\
\hline 2.1. & Карпов В. Діяльність ЦМЗСУ у 2000 році & Військовий музей. № 2. 2001. С. 90-101 \\
\hline 2.2 . & Карпов В. Діяльність ЦМЗСУ у 2001 році & Військовий музей. № 3. 2002. С. 191-200 \\
\hline 2.3 . & Карпов В. Діяльність ЦМЗСУ у 2002 році & Військовий музей. № 4. 2003. С. 105-120 \\
\hline 2.4. & Карпов В. Діяльність ЦМЗСУ у 2003 році & Військовий музей. № 5. 2004. С. 179-200 \\
\hline 2.5 . & Скрябін О. Звіт ЦМЗСУ про діяльність у 2004 році & Військовий музей. № 6. 2005. С. 159-187 \\
\hline 2.6. & Скрябін О. Звіт ЦМЗСУ про діяльність у 2005 році & Військовий музей. № 7. 2006. С. 167-199 \\
\hline 2.7. & Скрябін О. Звіт ЦМЗСУ про діяльність у 2006 році & Військовий музей. № 8. 2007. С. 204-250 \\
\hline 2.8. & Скрябін О. Звіт ЦМЗСУ про діяльність у 2007 році & Військовий музей. № 9. 2008. С. 74-124 \\
\hline 2.9 . & $\begin{array}{l}\text { Мороз І. Інформаційні технології в діяльності музею. } \\
\text { Основні показники роботи ЦМЗСУ у } 2008 \text { році }\end{array}$ & $\begin{array}{l}\text { Український військовий музей. № } 1 . \\
\text { 2009. С. 18-22 }\end{array}$ \\
\hline 3. & \multicolumn{2}{|l|}{ Співробітництво ЦМЗСУ (НВІМУ) (у т.ч. міжнародне) } \\
\hline 3.1. & $\begin{array}{l}\text { Седак Н. Відродження історичної спадщини українсько- } \\
\text { го народу - спільне завдання Українського інституту } \\
\text { воєнної історії та військових музеїв }\end{array}$ & Військовий музей. № 2. 2001. С. 88-89 \\
\hline 3.2 . & $\begin{array}{l}\text { Скрябін О. Співробітництво ЦЗМСУ з Королівським му- } \\
\text { зеєм армії та військової історії ЗС Бельгії }\end{array}$ & Військовий музей. № 5. 2004. С. 226-227 \\
\hline 3.3 . & $\begin{array}{l}\text { Чичкань І., Уткін О. Україна у Другій світовій війні. Ціна } \\
\text { Перемоги. Уроки (За матеріалами Круглого столу) }\end{array}$ & Військовий музей. № 6. 2005. С. 188-206 \\
\hline 3.4 . & $\begin{array}{l}\text { Карпов В. Симпозіум «Уніформа: вчора, сьогодні, зав- } \\
\text { тра» в Королівському музеї армії та військової історії } \\
\text { Бельгії }\end{array}$ & Військовий музей. № 7. 2006. С. 158-160 \\
\hline 3.5 . & $\begin{array}{l}\text { Корніснко О. Всеукраїнська акція «Музейна по- } \\
\text { дія року - 2010» }\end{array}$ & $\begin{array}{l}\text { Український військовий музей. № } 3 . \\
\text { 2011. С. } 12\end{array}$ \\
\hline 3.6. & Корнієнко О. Міжнародна музейна співпраця & $\begin{array}{l}\text { Український військовий музей. № } 3 . \\
\text { 2011. С. } 14\end{array}$ \\
\hline
\end{tabular}




\begin{tabular}{|c|c|c|}
\hline & Групи публікацій / Назва статті & Видання \\
\hline 4. & \multicolumn{2}{|l|}{ Експозиційна робота ЦМЗСУ } \\
\hline 4.1. & Седак Н. Миротворці України & Військовий музей. № 3. 2002. С. 205-206 \\
\hline 4.2 . & Чичкань І., Баята Л. Свідок жертовності і звитяги & Військовий музей. № 5. 2004. С. 203-207 \\
\hline 4.3 . & Єфімова І. «Небо війни» & Військовий музей. № 5. 2004. С. 208-210 \\
\hline 4.4 . & $\begin{array}{l}\text { Чичкань І., Баята Л. Концепція експозиції ЦМЗСУ } \\
\text { «Збройні Сили України. Створення, реформування, роз- } \\
\text { виток (1991-2004 рр.) }\end{array}$ & Військовий музей. № 5. 2004. С. 211-217 \\
\hline 4.5 . & Чичкань I. Фотовиставка «Діти війни» & Військовий музей. № 6. 2005. С. 207-213 \\
\hline 4.6. & $\begin{array}{l}\text { Іонова Т. Воєнними шляхами України та Європи. } \\
\text { Уславлені частини як предмет виставки }\end{array}$ & Військовий музей. № 7. 2006. С. 138-150 \\
\hline 5. & \multicolumn{2}{|l|}{ Фондова колекція ЦМЗСУ (НВІМУ) } \\
\hline 5.1. & $\begin{array}{l}\text { Денисюк Ж. Французька гвинтівка системи Шасспо-Гра } \\
\text { зразка 1866-1874 pp. }\end{array}$ & $\begin{array}{l}\text { Український військовий музей. № } 1 . \\
\text { 2009. С. 52-53 }\end{array}$ \\
\hline 5.2 . & $\begin{array}{l}\text { Денисюк Ж. Бойовий прапор 3-ї Залізної стрілецької } \\
\text { дивізії Армії УНР }\end{array}$ & $\begin{array}{l}\text { Український військовий музей. № } 1 . \\
\text { 2009. С. 63-55 }\end{array}$ \\
\hline 5.3. & Денисюк Ж. Звитяга, втілена в мистецтві & $\begin{array}{l}\text { Український військовий музей. № } 2 . \\
\text { 2010. С. 45-46 }\end{array}$ \\
\hline 5.4. & К Ж. Сим & $\begin{array}{l}\text { Український військовий музей. № } 2 . \\
\text { 2010. С. 63-65 }\end{array}$ \\
\hline 5.5. & $\begin{array}{l}\text { Денисюк Ж. Друковані видання та ілюстрована періо- } \\
\text { дика часів Першої світової війни }\end{array}$ & $\begin{array}{l}\text { Український військовий музей. № } 3 . \\
\text { 2011. С. 42-45 }\end{array}$ \\
\hline 5.6. & $\begin{array}{l}\text { Денисюк Ж. Михайло Кирпонос: героїзм і трагедія обо- } \\
\text { рони Києва } 1941 \text { р. }\end{array}$ & $\begin{array}{l}\text { Український військовий музей. № } 3 . \\
\text { 2011. С. 66-69 }\end{array}$ \\
\hline 5.7. & Денисюк Ж. Корейська війна в долі українця із США & $\begin{array}{l}\text { Український військовий музей. № } 4 . \\
\text { 2012. С. 40-44 }\end{array}$ \\
\hline 5.8. & $\begin{array}{l}\text { Денисюк Ж. Шаблі з Параду Перемоги Терентія Уман- } \\
\text { ського та Олександра Осадчого }\end{array}$ & $\begin{array}{l}\text { Український військовий музей. № } 4 . \\
\text { 2012. С. 45-49 }\end{array}$ \\
\hline 5.9. & $\begin{array}{l}\text { Давидюк В. Унікальний музейний експонат - ветери- } \\
\text { нарна сумка з малим хірургічним набором }\end{array}$ & $\begin{array}{l}\text { Український військовий музей. № } 1 . \\
\text { 2009. С. 39-41 }\end{array}$ \\
\hline 5.10 & $\begin{array}{l}\text { Давидюк В. Ручні гранати на фронтах Першої світової } \\
\text { війни 1914-1918 років }\end{array}$ & $\begin{array}{l}\text { Український військовий музей. № } 1 . \\
\text { 2009. С. 72-74 }\end{array}$ \\
\hline 5.11 & $\begin{array}{l}\text { Давидюк В. Висотний компенсуючий костюм пілота } \\
\text { ВКК 6М }\end{array}$ & $\begin{array}{l}\text { Український військовий музей. № } 2 . \\
\text { 2010. С. 47-48 }\end{array}$ \\
\hline 5.12 & $\begin{array}{l}\text { Давидюк В. Біноклі Робітничо-селянської червоної ар- } \\
\text { мії 1920-1940-х років }\end{array}$ & $\begin{array}{l}\text { Український військовий музей. № } 2 . \\
\text { 2010. С. 60-62 }\end{array}$ \\
\hline 5.13 & $\begin{array}{l}\text { Давидюк В. Кулеметна тачанка часів громадянської } \\
\text { війни 1918-1921 рр. у експозиції НВІМУ }\end{array}$ & $\begin{array}{l}\text { Український військовий музей. № } 3 . \\
\text { 2011. С. } 46-48\end{array}$ \\
\hline 5.14 & $\begin{array}{l}\text { Давидюк В. Матеріали генерал-полковника Л.І. Кожу- } \\
\text { хова як джерело вивчення історії військового будівниц- } \\
\text { тва СРСР }\end{array}$ & $\begin{array}{l}\text { Український військовий музей. № } 3 . \\
\text { 2011. С. 70-73 }\end{array}$ \\
\hline
\end{tabular}


Продовження дод. 1

\begin{tabular}{|c|c|c|c|}
\hline & Групи публікацій / Назва статті & \multicolumn{2}{|l|}{ Видання } \\
\hline 5.15 & $\begin{array}{l}\text { Давидюк В. Пістолет «Форт-17р» генерала армії Украї- } \\
\text { ни Івана Свиди }\end{array}$ & $\begin{array}{l}\text { Український військови } \\
\text { 2012. С. 34-35 }\end{array}$ & музей. № 4. \\
\hline 5.16. & $\begin{array}{l}\text { Давидюк В. Бойові прапори Військового двічі орденів } \\
\text { Червоного прапора інституту Ракетних військ і артиле- } \\
\text { рії імені Б. Хмельницького Сумського державного уні- } \\
\text { верситету }\end{array}$ & $\begin{array}{l}\text { Український військови } \\
\text { 2012. С. 36-39 }\end{array}$ & музей. № 4. \\
\hline 5.17 . & $\begin{array}{l}\text { Єрощенко О. Зброя Першої світової війни: гвинтівка } \\
\text { системи Росса }\end{array}$ & $\begin{array}{l}\text { Український військови } \\
\text { 2010. С. 49-50 }\end{array}$ & музей. № 2. \\
\hline 5.18 . & Єрощенко О. Танковий кулемет ДТ-29 & $\begin{array}{l}\text { Український військов } \\
\text { 2010. С. 55-58 }\end{array}$ & музей. № 2. \\
\hline 5.19 . & Єрощенко О. Японський пістолет Намбу. Тип 94 & $\begin{array}{l}\text { Український військови } \\
\text { 2011. С. } 49\end{array}$ & музей. № 3. \\
\hline 5.20 . & $\begin{array}{l}\text { Петренко Є. Особова справа двічі Героя Радянського } \\
\text { Союзу, генерал-майора Ковпака Сидора Артемовича }\end{array}$ & $\begin{array}{l}\text { Український військови } \\
\text { 2009. С. 50-51 }\end{array}$ & музей. № 1. \\
\hline 5.21 & $\begin{array}{l}\text { Петренко С. Нагороди гетьмана України Павла Петро- } \\
\text { вича Скоропадського }\end{array}$ & $\begin{array}{l}\text { Український військов } \\
\text { 2009. С. } 75-77\end{array}$ & музей. № 1. \\
\hline 5.22 . & $\begin{array}{l}\text { Руденко С. Історична постать командарма С.С. Ка- } \\
\text { менєва }\end{array}$ & $\begin{array}{l}\text { Український військови } \\
\text { 2009. С. 58-62 }\end{array}$ & музей. № 1. \\
\hline 5.23. & $\begin{array}{l}\text { Руденко С. Булави й кистені раннього Середньовіччя } \\
\text { з експозиції НВІМУ }\end{array}$ & $\begin{array}{l}\text { Український військови } \\
\text { 2010. С. 51-54 }\end{array}$ & музей. № 2. \\
\hline 5.24. & $\begin{array}{l}\text { Руденко С. Давньоруські амулети з експозиції НВІМУ } \\
\text { як джерела історико-культурної інформації }\end{array}$ & $\begin{array}{l}\text { Український військови } \\
\text { 2011. С. 50-53 }\end{array}$ & музей. № 3. \\
\hline 5.25 & Кучинський Б. Кітель маршала авіації О.І. Покришкіна & $\begin{array}{l}\text { Український військови } \\
\text { 2009. С. 66-71 }\end{array}$ & музей. № 1. \\
\hline 5.26. & $\begin{array}{l}\text { Мороз І. Форма одягу та знаки розрізнення «синьожу- } \\
\text { панників» }\end{array}$ & $\begin{array}{l}\text { Український військови } \\
\text { 2011. С. 35-37 }\end{array}$ & музей. № 3. \\
\hline 5.27. & $\begin{array}{l}\text { Горєлов В. Середній танк вермахту T-III (Pz. KPFW. III) } \\
\text { модифікації Aust. E (SD.KFZ. 141/1) }\end{array}$ & $\begin{array}{l}\text { Український військови } \\
\text { 2012. С. 31-33 }\end{array}$ & музей. № 4. \\
\hline 5.28. & $\begin{array}{l}\text { Курсаніна Н. Матроський ніж капітана I рангу } \\
\text { А.М. Шапошникова }\end{array}$ & $\begin{array}{l}\text { Український військови } \\
\text { 2012. С. 56-57 }\end{array}$ & музей. № 4. \\
\hline 5.29 . & Курсаніна Н. Турецький ятаган & $\begin{array}{l}\text { Український військови } \\
\text { 2012. С. 58-59 }\end{array}$ & музей. № 4. \\
\hline 5.30 & $\begin{array}{l}\text { Міненко Л., Ляшенко К., Корніснко О. Збереження } \\
\text { пам’яті про учасників афганської війни в експонатах } \\
\text { НВІМУ }\end{array}$ & $\begin{array}{l}\text { Український військови } \\
\text { 2012. С. 60-63 }\end{array}$ & музей. № 4. \\
\hline 5.31 . & $\begin{array}{l}\text { Слободинський Д. Зброя Другої світової війни: 75-мм } \\
\text { ствол протитанкової німецької гармати РаК } 40\end{array}$ & $\begin{array}{l}\text { Український військови } \\
\text { 2012. С. } 74-75\end{array}$ & музей. № 4. \\
\hline
\end{tabular}




\begin{tabular}{|c|c|c|}
\hline & Групи публікацій / Назва статті & Видання \\
\hline 6. & \multicolumn{2}{|c|}{ Методичне забезпечення організації фондової роботи у військових музеях } \\
\hline 6.1. & Денисюк Ж. Організація бібліотечної роботи у ЗСУ & Військовий музей. № 4. 2003. С. 121-123 \\
\hline 6.2 . & $\begin{array}{l}\text { Денисюк Ж. Наукове комплектування фондів - обов'я- } \\
\text { зок кожного наукового працівника музею }\end{array}$ & Військовий музей. № 6. 2005. С. 148-150 \\
\hline 6.3 . & $\begin{array}{l}\text { Денисюк Ж. Комплектування фондів та наукові дослі- } \\
\text { дження музейних предметів }\end{array}$ & $\begin{array}{l}\text { Український військовий музей. № } 1 \text {. } \\
\text { 2009. С. 23-27 }\end{array}$ \\
\hline 6.4 . & $\begin{array}{l}\text { Денисюк Ж. Музейний предмет як джерело військової } \\
\text { історії }\end{array}$ & $\begin{array}{l}\text { Український військовий музей. № } 2 \text {. } \\
\text { 2010. С. 28-31 }\end{array}$ \\
\hline 6.5 . & $\begin{array}{l}\text { Давидюк В. Основні напрями науково-фондової роботи } \\
\text { ЦМЗСУ з комплектування музейного зібрання }\end{array}$ & Військовий музей. № 8. 2007. С. 183-189 \\
\hline 6.6 . & Бутко Т. Аспекти пошукової роботи ЦЗМСУ & $\begin{array}{l}\text { Український військовий музей. № } 1 \text {. } \\
\text { 2009. С. 28-30 }\end{array}$ \\
\hline 6.7 . & $\begin{array}{l}\text { Руденко С. Грошова оцінка музейних предметів, що на- } \\
\text { лежать до зібрання НВІМУ }\end{array}$ & $\begin{array}{l}\text { Український військовий музей. № } 2 \text {. } \\
\text { 2010. С. 11-14 }\end{array}$ \\
\hline 7. & \multicolumn{2}{|c|}{ Методичне забезпечення організації роботи військових музеїв } \\
\hline 7.1. & $\begin{array}{l}\text { Седак Н.В., Денисюк Ж.З. Методика організації та про- } \\
\text { ведення тематичних виставок у військово-історичному } \\
\text { музеї (з практики роботи ЦМЗСУ) }\end{array}$ & Військовий музей. № 2. 2001. С. 102-113 \\
\hline 7.2 . & Остапенко Ю. Методика проведення виставок у музеї & Військовий музей. № 6. 2005. С. 156-158 \\
\hline 7.3 . & $\begin{array}{l}\text { Остапенко Ю. Екскурсія як одна з основних форм куль- } \\
\text { турно-освітньої діяльності }\end{array}$ & Військовий музей. № 5. 2004. С. 228-233 \\
\hline 7.4 . & $\begin{array}{l}\text { Губченко О. Основи забезпечення збереженості доку- } \\
\text { ментів і музейне зібрання }\end{array}$ & Військовий музей. № 6. 2005. С. 151-155 \\
\hline 7.5. & Єфімова I. Менеджмент і маркетинг у музейній справі & Військовий музей. № 5. 2004. С. 234-250 \\
\hline 8. & \multicolumn{2}{|l|}{ Робота філій ЦМЗСУ (НВІМУ) } \\
\hline 8.1. & \multicolumn{2}{|c|}{ Волинський регіональний музей украӥнського війська та військової техніки } \\
\hline 8.1.1. & $\begin{array}{l}\text { Єфімова І. Волинський регіональний музей українсько- } \\
\text { го війська та військової техніки: напрямки і перспекти- } \\
\text { ви розбудови }\end{array}$ & Військовий музей. № 4. 2003. С. 135-137 \\
\hline 8.1.2. & $\begin{array}{l}\text { Марищук Н. Про історію створення та проблеми діяль- } \\
\text { ності ВРМУВВТ }\end{array}$ & $\begin{array}{l}\text { Український військовий музей. № } 1 \text {. } \\
\text { 2009. С. 14-17. }\end{array}$ \\
\hline \multirow[t]{2}{*}{ 8.1.3. } & $\begin{array}{l}\text { Карпов В. Початковий період діяльності філії ЦМЗ- } \\
\text { СУ — ВРМУВВТ }\end{array}$ & $\begin{array}{l}\text { Український військовий музей. № } 1 \text {. } \\
\text { 2009. С. 35-38. }\end{array}$ \\
\hline & \multicolumn{2}{|l|}{ З фондів ВРМУВВТ } \\
\hline 8.1.4. & Соловський С. Фронтовий бомбардувальник СУ-24 & $\begin{array}{l}\text { Український військовий музей. № } 2 \text {. } \\
\text { 2010. С. 66-68 }\end{array}$ \\
\hline 8.1.5. & Соловський С. Останній Сталін & $\begin{array}{l}\text { Український військовий музей. № } 3 \text {. } \\
\text { 2011. С. 74-76 }\end{array}$ \\
\hline
\end{tabular}


Продовження дод. 1

\begin{tabular}{|c|c|c|}
\hline & Групи публікацій / Назва статті & Видання \\
\hline 8.1.6. & Чичерська О. БРДМ-2. У дозорі і в розвідці & $\begin{array}{l}\text { Український військовий музей. № } 2 . \\
\text { 2010. С. } 72-73\end{array}$ \\
\hline 8.1.7. & Марищук Н. ICУ-152. Винищувач важкої артилерії & $\begin{array}{l}\text { Український військовий музей. № } 2 . \\
\text { 2010. С. } 77-79\end{array}$ \\
\hline 8.1.8. & $\begin{array}{l}\text { Карпюк В. Артилерійська граната і картеч у період вій- } \\
\text { ни } 1812 \text { р. }\end{array}$ & $\begin{array}{l}\text { Український військовий музей. № } 4 . \\
\text { 2012. С. } 48-50\end{array}$ \\
\hline 8.1 .9 . & $\begin{array}{l}\text { Пасюк І. Волиняни — повні кавалери орденів Вітчиз- } \\
\text { няної війни }\end{array}$ & $\begin{array}{l}\text { Український військовий музей. № } 4 . \\
\text { 2012. С. 64-67 }\end{array}$ \\
\hline 8.1 .10 & Пасюк І. Військові сторінки життя В.К. Липинського & $\begin{array}{l}\text { Український військовий музей. № } 4 . \\
\text { 2012. С. 68-73 }\end{array}$ \\
\hline \multirow[t]{2}{*}{8.1 .11} & $\begin{array}{l}\text { Чичерська О. Перший надзвуковий винищувач-бом- } \\
\text { бардувальник Су-7б }\end{array}$ & $\begin{array}{l}\text { Український військовий музей. № } 4 . \\
\text { 2012. С. 76-79 }\end{array}$ \\
\hline & \multicolumn{2}{|l|}{ Про ВРМУВВТ з інших джерел } \\
\hline 8.1 .12 & $\begin{array}{l}\text { Чисюк Я. І оживе військова історія. У Луцьку створю- } \\
\text { ється Волинський регіональний музей українського } \\
\text { війська та військової техніки }\end{array}$ & Газета «Народна армія». 7 квітня 1999 \\
\hline 8.1 .13 & Військовий музей & «Волинь». 11 березня 2000 \\
\hline 8.2 . & \multicolumn{2}{|l|}{ Музей Ракетних військ стратегічного призначення } \\
\hline 8.2.1. & Тарасенко Л. Подія у Первомайську & Військовий музей. № 8. 2007. С. 193-196 \\
\hline 8.2.2. & $\begin{array}{l}\text { Тарасенко Л. Комплектування фондів - один із го- } \\
\text { ловних напрямів формування джерельної бази музею } \\
\text { РВСП. }\end{array}$ & $\begin{array}{l}\text { Військовий музей. № 7. 2006. С. 161- } \\
166 .\end{array}$ \\
\hline 8.2.3. & $\begin{array}{l}\text { Тарасенко Л. Зустрічаючи перший ювілей... (10 років } \\
\text { з дня створення філії НВІМУ - МРВСП) }\end{array}$ & $\begin{array}{l}\text { Український військовий музей. № } 2 . \\
\text { 2010. С. 21-23 }\end{array}$ \\
\hline \multirow[t]{2}{*}{ 8.2.4. } & $\begin{array}{l}\text { Тарасенко Л. Еволюція командних пунктів, або екс- } \\
\text { курс у майбутні експозиції МРВСП }\end{array}$ & $\begin{array}{l}\text { Український військовий музей. № } 4 . \\
\text { 2012. С. 8-10 }\end{array}$ \\
\hline & \multicolumn{2}{|l|}{3 фондів МРВСП } \\
\hline 8.2 .5 & Тарасенко О. Від ракет до експонатів музею & $\begin{array}{l}\text { Український військовий музей. № } 1 . \\
\text { 2009. С. 11-13 }\end{array}$ \\
\hline 8.2.6. & $\begin{array}{l}\text { Тарасенко О. Дніпровський первісток - стратегічна } \\
\text { ракета середньої дальності Р-12 }\end{array}$ & $\begin{array}{l}\text { Український військовий музей. № } 4 . \\
\text { 2012. С. 29-30 }\end{array}$ \\
\hline 8.2.7. & Тарасенко Л. Ракета РС-20 В: траєкторія долі & $\begin{array}{l}\text { Український військовий музей. № } 1 . \\
\text { 2009. С. 45-49 }\end{array}$ \\
\hline 8.2.8. & $\begin{array}{l}\text { Тарасенко Л. Крилаті ракети в небі і на землі. Макет } \\
\text { авіаційної крилатої ракети X-22 - експонат МРВСП }\end{array}$ & $\begin{array}{l}\text { Український військовий музей. № } 3 . \\
\text { 2011. С. 57-60 }\end{array}$ \\
\hline 8.2.9. & Распаріна Т. Танк-55 — головна ударна сила військ & $\begin{array}{l}\text { Український військовий музей. № } 2 . \\
\text { 2010. С. 69-71 }\end{array}$ \\
\hline 8.2 .10 & $\begin{array}{l}\text { Бублик С. Уніфікований командний пункт ракетного } \\
\text { полку }\end{array}$ & $\begin{array}{l}\text { Український військовий музей. № } 3 . \\
\text { 2011. С. 54-56 }\end{array}$ \\
\hline
\end{tabular}


Продовження дод. 1

\begin{tabular}{|c|c|c|}
\hline & Групи публікацій / Назва статті & Видання \\
\hline & $\begin{array}{l}\text { Ксензов В. Установник ракети як один із засобів забез- } \\
\text { печення ракетного комплексу }\end{array}$ & $\begin{array}{l}\text { Український військовий музей. № } 3 . \\
\text { 2011. С. 77-79 }\end{array}$ \\
\hline \multirow[t]{2}{*}{8.2 .12} & $\begin{array}{l}\text { Камєнсков М. Протипіхотна міна МОН-50 - зброя } \\
\text { війни }\end{array}$ & $\begin{array}{l}\text { Український військовий музей. № } 4 . \\
\text { 2012. С. 27-28 }\end{array}$ \\
\hline & \multicolumn{2}{|l|}{ Про МРВСП з інших джерел } \\
\hline 8.2.13. & Росляк Р. Грізну зброю не забудуть & Газета «Народна армія». 17 травня 2001 \\
\hline 8.2 .14 & $\begin{array}{l}\text { Тимчук Д. Остання пускова. В Україні завершено лік- } \\
\text { відацію шахтно-пускових установок МБР }\end{array}$ & $\begin{array}{l}\text { Газета «Народна армія». } 06 \text { листопада } \\
2001\end{array}$ \\
\hline 8.2 .15 & «Запустить» ракету сможет каждый & Газета «Сегодня». 06 грудня 2001 \\
\hline 8.2 .16 & Какой «ракетный щит» мы потеряли & $\begin{array}{l}\text { Газета «Киевский регион». № 9. 07-13 } \\
\text { марта } 2002\end{array}$ \\
\hline 8.2 .17 & Росляк Р. У Євразії такий музей — єдиний & Газета «Народна армія». 09 жовтня 2003 \\
\hline 8.2 .18 & Тищук Є. «Скальпель», що нікому не загрожує & Газета «Народна армія». 02 червня 2005 \\
\hline 8.3 . & \multicolumn{2}{|l|}{ Військово-морський музейний комплекс «Балаклава» } \\
\hline 8.3.1. & $\begin{array}{l}\text { Левченко М. Міжнародний фестиваль сучасного мис- } \\
\text { тецтва «Балаклавська Одисея» }\end{array}$ & вий музей. № 7. 2006. С. 151-157 \\
\hline 8.3.2. & $\begin{array}{l}\text { Чичкань І., Веселюк Т. Науково-практичний семінар } \\
\text { у ВММК «Балаклава» — філії ЦЗМСУ }\end{array}$ & Військовий музей. № 8. 2007. С. 190-192 \\
\hline 8.3.3. & $\begin{array}{l}\text { Чичкань І., Веселюк Т. Концепція музейної експозиції } \\
\text { філії ЦМЗСУ — ВММК «Балаклава» «Підводні сили } \\
\text { на Чорному морі». }\end{array}$ & $\begin{array}{l}\text { Військовий музей. № 8. 2007. С. 132- } \\
152 .\end{array}$ \\
\hline \multirow[t]{2}{*}{8.3 .4} & $\begin{array}{l}\text { Чичкань І., Веселюк Т. Концепція музейної експозиції } \\
\text { філії ЦМЗСУ - ВММК «Балаклава» «Холодна війна». } \\
\text { Військово-морський аспект» }\end{array}$ & $\begin{array}{l}\text { Військовий музей. № 8. 2007. С. 153- } \\
163 .\end{array}$ \\
\hline & \multicolumn{2}{|l|}{3 фондів ВММК «Балаклава» } \\
\hline 8.3.5. & $\begin{array}{l}\text { Ляховська К. Елементи корпусу підводного човна спе- } \\
\text { ціального призначення «Кефаль». Експонати музей- } \\
\text { ної експозиції «Підводні сили Чорноморського флоту } \\
\text { 1944-1994 рр.» ВММК «Балаклава» }\end{array}$ & $\begin{array}{l}\text { Український військовий музей. № } 1 . \\
\text { 2009. С. 42-44 }\end{array}$ \\
\hline 8.3.6. & $\begin{array}{l}\text { Іванов Я. Випробування нових видів озброєння на по- } \\
\text { лігоні мису Фіолент на добу «холодної війни» }\end{array}$ & $\begin{array}{l}\text { Український військовий музей. № } 2 . \\
\text { 2010. С. 32-34 }\end{array}$ \\
\hline 8.3.7. & $\begin{array}{l}\text { Іванов Я. Історія 381-го Севастопольського дивізіону } \\
\text { підводних човнів Чорноморського флоту }\end{array}$ & $\begin{array}{l}\text { Український військовий музей. № } 3 . \\
\text { 2011. С. 26-29 }\end{array}$ \\
\hline 8.3.8. & $\begin{array}{l}\text { Іванов Я. Підводні сили Чорноморського флоту СРСР } \\
\text { періоду «холодної війни» }\end{array}$ & $\begin{array}{l}\text { Український військовий музей. № } 4 . \\
\text { 2012. С. 23-26 }\end{array}$ \\
\hline 8.3.9. & $\begin{array}{l}\text { Архангельська-Зав’ялова О. Підводні човни проекту } \\
\text { 641: історія і сучасність }\end{array}$ & $\begin{array}{l}\text { Український військовий музей. № } 2 . \\
\text { 2010. С. } 35-38\end{array}$ \\
\hline
\end{tabular}


Продовження дод. 1

\begin{tabular}{|c|c|c|}
\hline & Групи публікацій / Назва статті & Видання \\
\hline 8.3.10. & $\begin{array}{l}\text { Архангельська-Зав’ялова О. } 3 \text { історії підземних спо- } \\
\text { руд... Об'єкт } 825 \text { ГТС }\end{array}$ & $\begin{array}{l}\text { Український військовий музей. № } 3 . \\
\text { 2011. С. 19-25 }\end{array}$ \\
\hline 8.3 .11 & $\begin{array}{l}\text { Троцак М. } 3 \text { історії секретного об’єкта радянського } \\
\text { Чорноморського флоту № } 820 \text { РТБ (в/ч № 90989) }\end{array}$ & $\begin{array}{l}\text { Український військовий музей. № } 2 . \\
\text { 2010. С. 39-44 }\end{array}$ \\
\hline 8.3.12. & $\begin{array}{l}\text { Троцак М. Флагман Військово-Морських сил України } \\
\text { «Гетьман Сагайдачний» }\end{array}$ & $\begin{array}{l}\text { Український військовий музей. № } 3 . \\
\text { 2011. С. 38-41 }\end{array}$ \\
\hline 8.3 .13 & Баженов Р. Як-38. Палубний штурмовик & $\begin{array}{l}\text { Український військовий музей. № } 2 . \\
\text { 2010. С. } 74-76\end{array}$ \\
\hline \multirow[t]{2}{*}{8.3 .14} & Бержицька С. Підводні човни проекту 613 & $\begin{array}{l}\text { Український військовий музей. № } 4 . \\
\text { 2012. С. 18-22 }\end{array}$ \\
\hline & \multicolumn{2}{|l|}{ Про ВММК «Балаклава» 3 інших джерел } \\
\hline 8.3 .15 & $\begin{array}{l}\text { Семена М. Музей «Об’єкт } 825 \text { ГТС». Чи зможе Севас- } \\
\text { тополь вигідно продавати своє воєнне минуле }\end{array}$ & $\begin{array}{l}\text { Газета «Дзеркало тижня». № } 30.09 \text { серп- } \\
\text { ня } 2003\end{array}$ \\
\hline 8.3.16. & $\begin{array}{l}\text { Інтерв’ю з В. Карповим. «Балаклава» працюватиме на } \\
\text { імідж українського флоту }\end{array}$ & Газета «Народна армія». 17 травня 2003 \\
\hline 8.3 .17 & Інтерв’ю з В. Карповим. Кому заважає «Балаклава» & Газета «Народна армія». 19 серпня 2003 \\
\hline 8.3 .18 & $\begin{array}{l}\text { Турич Я. Як той, що в скалі сидить, мало не ковтнув } \\
\text { місто }\end{array}$ & $\begin{array}{l}\text { Газета «Українське слово». № 24. 09-15 } \\
\text { червня } 2004\end{array}$ \\
\hline 8.3 .19 & Музей «Балаклава» відчиняє двері & Газета «Народна армія». 03 серпня 2005 \\
\hline 8.3.20. & $\begin{array}{l}\text { Евграшина М., Озерян Е. Советский подземный комп- } \\
\text { лекс, созданный в Балаклаве для оснащения и ремонта } \\
\text { субмарин, мог выдержать ядерный удар силой в «п’ять } \\
\text { Хиросим» }\end{array}$ & Газета «Факты». 01 февраля 2006 \\
\hline 8.3.21. & Щербаков О. Музей «копає» в глибину & Газета «Народна армія». 08 липня 2006 \\
\hline 8.3.22. & $\begin{array}{l}\text { Інтерв’ю з В. Садовниченко. Унікальна «Балаклава»: } \\
\text { вчора, сьогодні, завтра }\end{array}$ & Газета «Народна армія». 28 лютого 2007 \\
\hline 8.4. & \multicolumn{2}{|l|}{ Військово-морський музей України } \\
\hline 8.4.1. & $\begin{array}{l}\text { Горєлов В. Михайлівський равелін у Севастополі та } \\
\text { потреба його музеєфікації }\end{array}$ & $\begin{array}{l}\text { Український військовий музей. № } 1 . \\
\text { 2009. С. 31-34 }\end{array}$ \\
\hline 8.4.2. & $\begin{array}{l}\text { Карпов В. Відкриття Військово-морського музею } \\
\text { України у Севастополі }\end{array}$ & $\begin{array}{l}\text { Український військовий музей. № } 2 . \\
\text { 2010. С. 24-27 }\end{array}$ \\
\hline 8.5. & \multicolumn{2}{|l|}{ Меморіальний комплекс «Пам'яті Героїв Крут» } \\
\hline 8.5.1. & $\begin{array}{l}\text { Сарана В. Меморіальний комплекс «Пам’яті Героїв } \\
\text { Крут» - символ жертовності і патріотизму }\end{array}$ & $\begin{array}{l}\text { Український військовий музей. № } 2 . \\
\text { 2010. С. 15-16 }\end{array}$ \\
\hline 8.5.2. & $\begin{array}{l}\text { Примушко Н. Меморіальний комплекс «Пам’яті Геро- } \\
\text { ї Крут» (історія створення та сьогодення) }\end{array}$ & $\begin{array}{l}\text { Український військовий музей. № } 4 . \\
\text { 2012. С. 3-7 }\end{array}$ \\
\hline 8.6. & \multicolumn{2}{|l|}{ Музей «Герої Дніпра» } \\
\hline 8.6.1. & Кваснюк Я. Скарбниця доблесті і звитяги & $\begin{array}{l}\text { Український військовий музей. № } 2 . \\
\text { 2010. С. 17-20 }\end{array}$ \\
\hline
\end{tabular}


Продовження дод. 1

\begin{tabular}{|c|c|c|}
\hline & Групи публікацій / Назва статті & Видання \\
\hline 8.6.2. & $\begin{array}{l}\text { Кваснюк Я. Бронепоїзд 77-го полку 10-ї дивізії НКВС } \\
\text { з охорони залізничних споруд }\end{array}$ & $\begin{array}{l}\text { Український військовий музей. № } 3 . \\
\text { 2011. С. 30-34 }\end{array}$ \\
\hline 8.6.3. & Кваснюк Я. Пі & $\begin{array}{l}\text { Український військовий музей. № } 3 . \\
\text { 2011. С. 61-65 }\end{array}$ \\
\hline 8.6.4. & к Я. «Сc & $\begin{array}{l}\text { Український військовий музей. № } 4 . \\
\text { 2012. С. 51-55 }\end{array}$ \\
\hline 9. & Український військовий музей & \\
\hline 9.1. & $\begin{array}{l}\text { Андресюк Б. Роль військових музеїв у збереженні } \\
\text { військово-історичної спадщини }\end{array}$ & $\begin{array}{l}\text { Український військовий музей. № } 2 . \\
\text { 2010. С. } 3\end{array}$ \\
\hline 9.2 . & $\begin{array}{l}\text { Діброва В. «Український військовий музей» - новий } \\
\text { погляд }\end{array}$ & $\begin{array}{l}\text { Український військовий музей. № } 1 . \\
\text { 2009. С. } 3\end{array}$ \\
\hline 9.3 . & $\begin{array}{l}\text { Чичкань I. Всеармійський огляд-конкурс військових } \\
\text { музеїв }\end{array}$ & Військовий музей. № 7. 2006. С. 93-95 \\
\hline 9.4 . & $\begin{array}{l}\text { Тищенко І. Організація діяльності, напрямки і пер- } \\
\text { спективи розвитку військових музеїв (кімнат) бойової } \\
\text { (трудової) слави у ЗСУ. Роль і місце ЦМЗСУ у системі } \\
\text { військово-музейної справи }\end{array}$ & $\begin{array}{l}\text { Український військовий музей. № } 1 . \\
\text { 2009. С. 4-5 }\end{array}$ \\
\hline 10. & Огля & \\
\hline 10.1 & Веселюк Т. Музей історії воєнної розвідки України & Військовий музей. № 7. 2006. С. 96-100 \\
\hline 10.2 . & $\begin{array}{l}\text { Дерновий В. Військово-історичний музей Повітряних } \\
\text { Сил ЗС України }\end{array}$ & $\begin{array}{l}\text { Український військовий музей. № } 1 . \\
\text { 2009. С. 93-94 }\end{array}$ \\
\hline 10.3 & $\begin{array}{l}\text { Куліш М. Підсумки діяльності військових музеїв ВМС } \\
\text { ЗС України }\end{array}$ & $\begin{array}{l}\text { Український військовий музей. № } 1 . \\
\text { 2009. С. } 86\end{array}$ \\
\hline 10.4 & $\begin{array}{l}\text { Михайловський Р., Глушко А. Музей Харківського уні- } \\
\text { верситету Повітряних сил ім. Івана Кожедуба }\end{array}$ & $\begin{array}{l}\text { Український військовий музей. № } 3 . \\
\text { 2011. С. 3-5 }\end{array}$ \\
\hline 10.5 & $\begin{array}{l}\text { Москаленко В. Військово-історичний комплекс «Ске- } \\
\text { ля» у місті Коростені }\end{array}$ & $\begin{array}{l}\text { Український військовий музей. № } 2 . \\
\text { 2010. С. 8-10 }\end{array}$ \\
\hline 10.6 & $\begin{array}{l}\text { Непота І. Основні результати роботи військових музеїв } \\
\text { та музеїв Повітряних Сил ЗС України }\end{array}$ & $\begin{array}{l}\text { Український військовий музей. № } 1 . \\
\text { 2009. С. 83-85 }\end{array}$ \\
\hline 10.7 . & $\begin{array}{l}\text { Паліса С. Воєнно-історичний музей 58-го Будинку офі- } \\
\text { церів }\end{array}$ & $\begin{array}{l}\text { Український військовий музей. № } 3 . \\
\text { 2011. С. 6-11 }\end{array}$ \\
\hline 10.8. & $\begin{array}{l}\text { Скрябін О. } 40 \text { років Військово-історичному музею Пів- } \\
\text { денного оперативного командування }\end{array}$ & Військовий музей. № 8. 2007. С. 197-203 \\
\hline 10.9 & $\begin{array}{l}\text { Скрябін О. Музеї та кімнати бойової слави військових } \\
\text { частин Сухопутних військ ЗС України }\end{array}$ & $\begin{array}{l}\text { Український військовий музей. № } 1 . \\
\text { 2009. С. 81-82 }\end{array}$ \\
\hline 10.10. & $\begin{array}{l}\text { Фоміна В. Музейне відображення образу противника } \\
\text { в головній експозиції МК «Національний музей історії } \\
\text { ВВВ 1941-1945 років». }\end{array}$ & Військовий музей. № 8. 2007. С. 164-175 \\
\hline
\end{tabular}


Закінчення дод. 1

\begin{tabular}{|c|c|c|}
\hline & Групи публікацій / Назва статті & Видання \\
\hline 10.11. & $\begin{array}{l}\text { Філатова Н. Традиції й надбання у науково-просвіт- } \\
\text { ницькій роботі Меморіалу над Дніпром }\end{array}$ & Військовий музей. № 8. 2007. С. 176-182 \\
\hline 10.12 . & горії воєнної розвідки & $\begin{array}{l}\text { Український військовий музей. № } 1 . \\
\text { 2009. С. 89-92 }\end{array}$ \\
\hline 10.13 . & $\begin{array}{l}\text { Чичкань I. Полтавська авіаційна колекція. Зустріч з іс- } \\
\text { торією }\end{array}$ & Військовий музей. № 4. 2003. С. 124-134 \\
\hline 11. & \multicolumn{2}{|l|}{ Аналіз роботи військових музеїв ЗС України } \\
\hline 11.1. & Седак Н. Розбудова військових музеїв & Військовий музей. № 3. 2002. С. 201-204 \\
\hline 11.2 . & $\begin{array}{l}\text { Остапенко Ю. Аналіз статистичного обліку даних ді- } \\
\text { яльності військових музеїв, музеїв (кімнат) бойової } \\
\text { (трудової) слави у ЗСУ у } 2003 \text { році }\end{array}$ & Військовий музей. № 5. 2004. С. 201-202 \\
\hline 11.3 . & $\begin{array}{l}\text { Єфімова І. Аналіз підсумків роботи військових музеїв } \\
\text { та музеїв (кімнат) бойової (трудової) слави за } 2007 \text { рік }\end{array}$ & Військовий музей. № 9. 2008. С. 57-73 \\
\hline 11.4. & $\begin{array}{l}\text { Колєснік І. Аналіз підсумків роботи військових музеїв } \\
\text { за } 2008 \text { рік }\end{array}$ & $\begin{array}{l}\text { Український військовий музей. № } 1 . \\
\text { 2009. С. } 78-80\end{array}$ \\
\hline 11.5 . & $\begin{array}{l}\text { Лазебник В. Аналіз роботи музейних утворень струк- } \\
\text { турних підрозділів МО України, ГШ ЗС України, вій- } \\
\text { ськових навчальних закладів }\end{array}$ & $\begin{array}{l}\text { Український військовий музей. № } 1 . \\
\text { 2009. С. } 87-88\end{array}$ \\
\hline 12. & \multicolumn{2}{|c|}{$\begin{array}{l}\text { Опис музейних предметів } 3 \text { приватних колекцій та висвітлення аспектів } \\
\text { військово-музейної справи на сторінках журналу «Військовий музей» } \\
\text { («Український військовий музей») }\end{array}$} \\
\hline 12.1. & Малаков Д. Запальнички часів Другої світової війни & $\begin{array}{l}\text { Український військовий музей. № } 2 . \\
\text { 2010. С. } 59\end{array}$ \\
\hline 12.2 . & $\begin{array}{l}\text { Ромадін С. Огляд деяких експозиційних особливостей } \\
\text { залізничної техніки бойового призначення }\end{array}$ & $\begin{array}{l}\text { Український військовий музей. № } 4 . \\
\text { 2012. С. 11-17 }\end{array}$ \\
\hline 12.3 . & $\begin{array}{l}\text { Шереметьєв О. Печатка Гуляйпільського воєнно-рево- } \\
\text { люційного партизанського польового штабу Повстан- } \\
\text { ської армії імені батька Махна }\end{array}$ & $\begin{array}{l}\text { Український військовий музей. № } 1 . \\
\text { 2009. С. 54-57 }\end{array}$ \\
\hline 12.4. & $\begin{array}{l}\text { Остапенко Ю. Дослідження інформаційно-музейних } \\
\text { технологій як один із головних напрямів діяльності му- } \\
\text { зею }\end{array}$ & Військовий музей. № 6. 2005. С. 144-147 \\
\hline 12.5 . & Ляшенко К. Музейники діляться досвідом & $\begin{array}{l}\text { Український військовий музей. № } 3 . \\
\text { 2011. С. } 13\end{array}$ \\
\hline
\end{tabular}




\section{СПИСОК ВИКОРИСТАНИХ ДЖЕРЕЛ І ЛІТЕРАТУРИ}

1. Аналіз підсумків роботи військових музеїв (музейних утворень) Збройних Сил України за 2011 рік. Архів НВІМ України (Наи. військ.-істор. муз. Украӥни). Док. фонд. 38 арк.; Там само за 2012 рік. Архів НВIM України. Док. фонд. 37 арк.; Там само за 2013 рік. Архів НВIM України. Док. фонд. 43 арк.; Там само за 2014 рік. Архів НВІМ України. Док. фонд. 44 арк.

2. Виховна робота у Збройних Силах України: підруч. [А. Кобзар, О. Копаниця, В. Грицюк та ін.]; за заг. Ред. Б. Андресюка. Чернівці : Місто, 2011. 408 с.

3. Звіт про діяльність Музею Збройних Сил України за 1996 рік. Архів НВIM України (Наи. військ.-істор. муз. Украӥни). Док. фонд. 5 арк.; Звіт про діяльність Центрального музею Збройних Сил України за 1998 рік. Архів НВIM України. Док. фонд. 4 арк.; Там само за 2000 рік. Архів НВІМ України. Док. фонд. 21 арк.; Там само за 2001 рік. Архів НВІм України. Док. фонд. 12 арк.; Там само за 2002 рік. Архів НВIM України. Док. фонд. 16 арк.; Там само за 2003 рік. Архів НВIM Украӥни. Док. фонд. 23 арк.; Там само за 2004 рік. Архів НВIM Украйни. Док. фонд. 39 арк.; Там само за 2005 рік. Архів НВІМ Украӥни. Док. фонд. 30 арк.; Там само за 2006 рік. Архів НВІМ України. Док. фонд. 31 арк.; Там само за 2007 рік. Архів НВІМ України. Док. фонд. 59 арк.; Там само за 2008 рік. Архів НВІМ Украӥни. Док. фонд. 54 арк. Там само за 2009 рік. Архів НВIM України. Док. фонд. 93 арк.; Звіт про діяльність Національного військово-історичного музею України за 2010 рік. Архів НВІМ України. Док. фонд. 85 арк.; Там само за 2011 рік. Архів НВІМ України. Док. фонд. 69 с.; Там само за 2012 рік. Архів НВІМ України. Док. фонд. 55 с.; Там само за 2013 рік. Архів НВІМ Украӥни. Док. фонд. 113 с.; Там само за 2014 рік. Архів НВІМ України. Док. фонд. 261 арк.

4. Карпов В. 100 років 3 дня створення першого військово-історичного музею в Україні. Військово-історичний альманах. № 2. 2010. С. 143-148.

5. KarpovV. Military museology in the period of the transgression of the society from 1989 to 1991. Вісник Національної академії керівних кадрів культури і мистецтвва. № 4. 2018. C. $43-48$.

6. Карпов В. Музейна справа у Збройних Силах України (1996-2006). Київ. НВІМУ.2007. $96 \mathrm{c}$.

7. Котвіцький В.В. Створення та розвиток музейних інституцій в Збройних Силах України (1991-1996 рр.). Воєнно-історичний вісник. № 1(23). 2017. С. 68-74.

8. Машталір В. Військово-історичні споруди XIX-XX століть як об'єкти культурної спадщини України : дис... канд. іст. наук: 26.00.05. Київ : Б.в., 2014. 210 с.

9. Машталір В. Генезис військово-історичного музейництва в Україні (кінець XIX - початок XXI століть) : дис...д-ра іст. наук: : 26.00.05. Київ : Б.в., 2019. 356 с.

10. Механізм. Словник української мови: в 11 тт. / АН УРСР. Інститут мовознавства; за ред. І.К. Білодіда. Київ : Наукова думка, 1970-1980. URL: http://sum.in.ua/s/mekhanizm (дата звернення: 24.06.2020 р.).

11. Міненко Л.М. Віктор Карпов - організатор першого військово-історичного музею Збройних Сил України. Воєнно-історичний вісник. № 4(26). 2017. С. 69-78.

12. Про затвердження Інструкції з організації діяльності військових музеїв, музеїв (кімнат) бойових традицій у Збройних Силах України: Наказ Міністра оборони України від 10 липня 2019 року № 374. URL: https://www.mil.gov.ua/content/mou_orders/mou_374.pdf (дата звернення: 17.06.2020). 
13. Про затвердження Положення про організацію діяльності військових музеїв та музеїв (кімнат) бойової (трудової) слави у Збройних Силах України: Наказ Міністра оборони України від 06.03.2002 р. № 95. ГДАМО Украӥни. Ф. 3697. Оп. А1П. Спр. 1497. Арк. 168-202.

14. Про затвердження Положення про організацію діяльності військових музеїв, музеїв (кімнат) бойових традицій у Збройних Силах України: Наказ Міністра оборони України від 17.07.2018 p. № 343. URL: https://www.mil.gov.ua/content/mou_orders/343_nm_2018.pdf (дата звернення: 17.06.2020).

15. Про затвердження Програми військово-патріотичного виховання у ЗС України на 2008-2011 роки та Перспективного плану реалізації військово-патріотичного виховання у ЗС України на 2008-2011 роки: Наказ Міністра оборони України від 09.07.2008 р. № 340. ГДАМО України. Ф. 3697. ОП. А1П. Спр. 1608. Арк. 212-234.

16. Якайтіс І.Б. Механізми державного управління інноваційним розвитком вищої освіти в Україні : дис. ...кан-та наук з держ. упр. : 25.00.02 / Ів.-Фр. нац. тех. ун-т нафти і газу MOH. Івано-Франківськ, 2018. 246 c. URL: https://nung.edu.ua/files/attachments/dis_yakaytis. pdf (дата звернення: 24.06.2020 р.).

\section{REFERENCES}

1. NVIM Ukrajiny. (2011, 2012, 2013, 2014). Analiz pidsumkiv roboty vijsjkovykh muzejiv (muzejnykh utvorenj) Zbrojnykh Syl Ukrajiny [Analysis of the results of the work of military museums (museum's institutions) of the Armed Forces of Ukraine for 2011] (Dok. Fond: 38 ark.; 37 ark.; 43 ark.; 44 ark.).ArkhivNVIMUkrajiny, Kyiv [In Ukrainian].

2. Kobzar A. (Red.). (2011). Vykhovnarobota u Zbrojnykh Sylakh Ukrajiny: pidruch. [Educational work in the Armed Forces of Ukraine: a textbook]. Chernivci : Misto [In Ukrainian].

3. NVIMUkrajiny. (1996, 1998, 2000, 2001, 2002, 2003, 2004, 2005, 2006, 2007, 2008, 2009, 2010, 2011, 2012, 2013, 2014). Zvit pro dijaljnistj Muzeju Zbrojnykh Syl Ukrajiny (1996) [Report on the activities of the Museum of the Armed Forces of Ukraine (1996)]; Zvit pro dijaljnistj Centraljnogho muzeju Zbrojnykh Syl Ukrajiny(1998, 2000, 2001, 2002, 2003, 2004, 2005, 2006, 2007, 2008, 2009) [Report on the activities of the Central Museum of the Armed Forces of Ukraine (1998, 2000, 2001, 2002, 2003, 2004, 2005, 2006, 2007, 2008, 2009)]; Zvit pro dijaljnij Nacionaljnogho vijsjkovo-istorychnogho muzeju Ukrajiny $(2010,2011,2012,2013,2014)$ [Report on the activities of the National Museum of Military History of Ukraine (2010, 2011, 2012, 2013, 2014)] (Dok. Fond:5 ark.; 4 ark.; 21 ark.; 12 ark.; 16 ark.; 23 ark.; 39 ark.; 30 ark.; 31 ark.; 59 ark.; 54 ark.; 93 ark.; 85 ark.; 69 s.; 55 s.; 113 s.; 261 ark.). Arkhiv NVIM Ukrajiny, Kyiv [In Ukrainian].

4. Karpov, V. (2010). 100 rokiv z dnja stvorennja pershogho vijsjkovo-istorychnogho muzeju $\mathrm{v}$ Ukrajini [100 years since the creation of the first museum of military history in Ukraine]. Vijsjkovo-istorychnyj aljmanakh,№ 2. S. 143-148 [In Ukrainian].

5. Karpov, V. (2018). Vijsjkove muzejeznavstvo u period transghresiji suspiljstva 1989-1991 rokiv [Military museum studies during the transgression of society in 1989-1991]. Visnyk Natsionalnoi akademii kerivnykh kadriv kultury i mystetstva. № 4. S. 43-48 [InUkrainian].

6. Karpov, V. (2007). Muzejna sprava u Zbrojnykh Sylakh Ukrajiny (1996-2006) [Museologyin the Armed Forces of Ukraine (1996-2006).]. Kyjiv : NVIMU. [InUkrainian]. 
7. Kotvicjkyj, V. (2017). Stvorennia ta rozvytok muzeinykh instytutsii v Zbroinykh Sylakh Ukrainy (1991-1996 rr.) [Creation and development of museum institutions in the Armed Forces of Ukraine (1991-1996)]. Voienno-istorychnyi visnyk. № 1(23). S. 68-74 [In Ukrainian].

8. Mashtalir, V. (2014). Vijsjkovo-istorychni sporudy XIX-XX stolitjja k ob’jekty kuljturnoji spadshhyny Ukrajiny [Military-historical buildingsofthe XIX-XX centuries as objects of cultural heritage of Ukraine]. (Dys... kand. ist. nauk).NAS of Ukraine, Ukr. t-vo protection of monuments of history and culture, Center for Monument Studies, Kyjiv[InUkrainian].

9. Mashtalir V. (2019). Ghenezys vijsjkovo-istorychnogho muzejnyctva v Ukrajini (kinecj XIX - pochatok XXI stolitj) [Genesisof military-historical museologyinUkraine (endof XIX - beginningof XXI centuries)] (Dys...d-raist. nauk). NAS of Ukraine, Ukr. t-vo protection of monuments of history and culture, Center for Monument Studies, Kyjiv [InUkrainian].

10. Bilodid, I. K. (Ed.) (1970-1980). Mekhanizm. Slovnyk ukrajinsjkoji movy: v 11 tt. [Mechanism. Dictionary of the Ukrainian language: in 11 vols].Kyjiv : Naukovadumka. Retrieved from http://sum.in.ua/s/mekhanizm [In Ukrainian].

11. Minenko, L.M. (2017). Viktor Karpov — orghanizator pershogho vijsjkovo-istorychnogho muzeju Zbrojnykh Syl Ukrajiny [Viktor Karpov is the organizer of the first military-historical museum of the Armed Forces of Ukraine]. Vojenno-istorychnyj visnyk, 4(26). S. 69-78 [In Ukrainian].

12. Nakaz Ministra oborony Ukrajiny. (2019 July 10). Pro zatverdzhennja Instrukciji z orghanizaciji dijaljnosti vijsjkovykh muzejiv, muzejiv (kimnat) bojovykhtradycij u Zbrojnykh Sylakh Ukrajiny [About the statement of the Instruction on the organization of activity of military museums, museums (rooms) of fighting traditions in the Armed Forces of Ukraine], № 374. Retrieved from https://www.mil.gov.ua/content/mou_orders/mou_374.pdf [In Ukrainian].

13. Ministrstvo oborony Ukrajiny. (2002 March 06.). Pro zatverdzhennja Polozhennja pro orghanizaciju dijaljnosti vijsjkovykh muzejiv ta muzejiv (kimnat) bojovoji (trudovoji) slavy u Zbrojnykh Sylakh Ukrajiny [About the statement of the Situation on the organization of activityof military museums and museums (rooms) ofmilitary (labor) glory in the Armed Forces of Ukraine], № 95 (F. 3697. Op. A1P. Spr. 1497. Ark. 168-202). GhDAMO Ukrajiny, Kyiv [In Ukrainian].

14. Ministrstvo oborony Ukrajiny. (2018 July 17). Pro zatverdzhennja Polozhennja pro orghanizaciju dijaljnosti vijsjkovykh muzejiv, muzejiv (kimnat) bojovykh tradyciju Zbrojnykh Sylakh Ukrajiny [On approval of the Regulations on the organization of the activities of military museums, museums (rooms) of military traditions in the Armed Forces of Ukraine], № 343. Retrieved from https://www.mil.gov.ua/content/mou_orders/343_nm_2018.pdf [In Ukrainian].

15. Ministrstvo oborony Ukrajiny. (2008 July 09) Pro zatverdzhennja Proghramy vijsjkovopatriotychnogho vykhovannja u ZS Ukrajinyna 2008-2011 roky ta Perspektyvnogho planu realizaciji vijsjkovo-patriotychnogho vykhovannja u ZS Ukrajinyna 2008-2011 roky [About approval of the Programof military-patriotic education in theArmed Forces of Ukrainefor 20082011 and the Perspective planof realization of military-patriotic education in the Armed Forces of Ukraine for 2008-2011], № 340 (F. 3697. Op. A1P. Spr. 1608. Ark. 212-234). GhDAMO Ukrajiny, Kyiv [In Ukrainian].

16. Jakajtis, I. B. (2018). Mekhanizmy derzhavnogho upravlinnja innovacijnym rozvytkom vyshhoji osvity v Ukrajini [Mechanisms of stateman agement of innovative development of highe reducation in Ukraine] (Dys. ...kan-tanaukzderzh. upr.). Iv.-Fr. nac. tekh. un-tnafty i ghazu MON. Ivano-Frankivsjk [In Ukrainian]. 
Minenko L.M., postgraduate students,

National academy of managerial

staff of culture and arts(Kyiv, Ukraine)

ORCID: https://orcid.org/0000-0003-0249-9856

\section{FORMATION OF THE NETWORK OF MILITARY MUSEUMS IN THE ARMED FORCES OF UKRAINE (1995-2013)}

In the article the author, using the method of analysis of sources and literature, conducted a detailed review of scientific works, which provided an opportunity to objectively reveal the preconditions and history of the formation and development of a network of military museums (museum formations) of the Armed Forces of Ukraine (AF of Ukraine) as a basis for building a system of educational and socio-psychological work in the period from 1995 to 2013. Using the diachronic method, the place and role of the National Museum of Military History of Ukraine (NMMHU) and its branches as the main active participants in this system were specified, and the activity of museum institutions of the Armed Forces of Ukraine was analyzed according to indicators reflecting the structure of stocks and cultural and educational work. Methods of compilation and grouping, tabular and graphical provided an opportunity to visually summarize the work of military museums (museum formations), which are part of the Ministry of Defense of Ukraine, the General Staff and the Directorate of Intelligence of the AF of Ukraine. At the same time, on the basis of the contextual-analytical method, the objective reasons that contributed to and, under certain circumstances, inhibited the receipt of positive results and their statistical-analytical fixation were identified. It is noted that the general organizational, scientific and methodological coordinator of the successful operation of the network of military museums and professional and patriotic engine of continuous improvement of the system of educational and socio-psychological work of the AF of Ukraine among servicemen and citizens in the period of study was de jure and de facto NMMHU. Specific examples of implementation, under the leadership of the main military museum institution, of the Program of military-patriotic education in the Armed Forces of Ukraine as a key reference point for the formation of the necessary axiological and patriotic features that contribute to reliable national security and defense are presented. As a result, emphasis was placed on the need to restore the key role of NMMHU, its branches and museums (museum formations) in the structure of the Ministry of Defense of Ukraine, the General Staff and the Directorate of Intelligence of the AF of Ukraine to preserve historical memory and proper appreciation of future generations of valor, victory, sacrifice, love, morality in this extremely difficult period of formation of our young state.

Key words: National Museum of Military History of Ukraine and its branches; network of military museums of the Armed Forces of Ukraine; system of educational and social-psychological work in the Armed Forces of Ukraine; informational-museum activities; stock work. 